\title{
The Prospects of Agricultural and Food Residue Hydrolysates for Sustainable Production of Algal Products
}

\author{
Ehab M. Ammar ${ }^{1,2,+} \oplus^{\circ}$, Neha Arora ${ }^{1, \dagger}$ and George P. Philippidis ${ }^{1, *}$ \\ 1 Patel College of Global Sustainability, University of South Florida, 4202 E. Fowler Avenue, Tampa, FL 33620, \\ USA; eammar@usf.edu (E.M.A.); nehaarora@usf.edu (N.A.) \\ 2 Genetic Engineering and Biotechnology Research Institute, University of Sadat City, P.O. Box 79/22857, \\ El-Sadat City, Egypt \\ * Correspondence: gphilippidis@usf.edu; Tel.: +1-813-974-9333 \\ + These authors contributed equally to this work.
}

Received: 2 November 2020; Accepted: 2 December 2020; Published: 4 December 2020

\begin{abstract}
The growing demand of microalgal biomass for biofuels, nutraceuticals, cosmetics, animal feed, and other bioproducts has created a strong interest in developing low-cost sustainable cultivation media and methods. Agricultural and food residues represent low-cost abundant and renewable sources of organic carbon that can be valorized for the cultivation of microalgae, while converting them from an environmental liability to an industrial asset. Biochemical treatment of such residues results in the release of various sugars, primarily glucose, sucrose, fructose, arabinose, and xylose along with other nutrients, such as trace elements. These sugars and nutrients can be metabolized in the absence of light (heterotrophic) or the presence of light (mixotrophic) by a variety of microalgae species for biomass and bioproduct production. The present review provides an up-to-date critical assessment of the prospects of various types of agricultural and food residues to serve as algae feedstocks and the microalgae species that can be grown on such residues under a range of cultivation conditions. Utilization of these feedstocks can create potential industrial applications for sustainable production of microalgal biomass and bioproducts.
\end{abstract}

Keywords: microalgae; agricultural residue; food residue; hydrolysate; biomass; biofuels; bioproducts

\section{Introduction}

Implementation of the sustainable development goals (SDGs) adopted by the United Nations is imperative for attaining a sustainable future. To achieve these goals, it is vital to utilize natural renewable resources as the basis for developing a bioeconomy. Among renewable resources, microalgae constitute a promising source of food, fiber, fuel, feed, and fertilizer, which are the 5Fs of the SDGs [1]. These microorganisms can also remediate various types of wastes (wastewater, heavy metals, toxic organic compounds) and act as a sink of $\mathrm{CO}_{2}$ from industrial flue gases and the atmosphere, thus contributing to climate change amelioration. Microalgae convert sunlight, $\mathrm{CO}_{2}$ and/or sugars, water, macronutrients (nitrogen and phosphorus), micronutrients, and trace elements into biomass that consists of lipids, proteins, and carbohydrates, which find applications in many sectors of the economy, as is detailed below [2]. Depending on the microalgal species, cultivation conditions, and light sources the biochemical composition of the microalgal biomass varies. Normally, microalgae tend to synthesize proteins, but they switch their metabolism to carbohydrate and lipid accumulation when subjected to environmental stressors [3]. 


\section{Microalgal Products}

Microalgal proteins are an excellent source of nutrition and have been utilized as food and animal feed since the 1950s [4]. Large-scale cultivation facilities of Chlorella sp. and Spirulina sp. (cyanobacteria) for human consumption are well established in Asia, U.S.A., and Australia [4]. The reported protein yields from microalgae are 4-15 tons/ha/year far exceeding the 1-2 tons/ha/year from terrestrial plants, such as wheat and soybean [5]. Microalgae-based protein is reportedly of better nutritional quality than plant-based protein from rice, wheat, and vegetables [6]. The quality of a protein is determined by its amino-acid composition, and microalgal proteins possess all the essential amino acids, including methionine and lysine, which are known to enhance animal growth [7]. Moreover, due to its high nutritional content and enhanced digestibility, microalgal biomass has been used in candies, gums, snacks, noodles, and cereals [5,8]. It should be noted that the amino acid composition of microalgae can be readily altered to fit market segment needs by changing the cultivation conditions or manipulating the genome of the microorganism. Microalgal biomass also contains an array of high-value compounds and elements, such as vitamins (A, B1, B2, B12, C, E), minerals ( $\mathrm{K}, \mathrm{Fe}, \mathrm{Mg}$, and $\mathrm{Ca})$, phycocyanin, and carotenoids (astaxanthin, $\beta$-carotene, lutein and lycopene), which are increasingly utilized in cosmetics, nutraceuticals, and food products $[4,9,10]$. Phycocyanin (phycobiliproteins), a component of the microalgal light-harvesting complex (LHC), encompasses colored proteins with linear tetrapyrrole prosthetic groups used as non-toxic food colorants, cosmetic ingredients, and nutraceuticals [11]. Carotenoids are an excellent source of anti-oxidants and functional foods that reportedly combat diseases, such as obesity, diabetes, Alzheimer's, cancer, and cardiovascular and neurological disorders [5]. To date, a few microalgal species belonging to Chlorophyta (Dunaliella salina, Haematococcus pluvalis, Chlorella vulgaris, Chlorella zofingienis, and Chlorella pyrenoidosa) have been listed as GRAS (generally recognized as safe) by the US Food and Drug Administration (FDA) and are successfully mass-produced [9].

Microalgal carbohydrates can be converted to biofuels, such as ethanol, and bulk chemicals. Biobased ethanol can be blended with conventional transportation fuels, such as gasoline, to reduce greenhouse gas emissions from the transportation sector [12]. Microalgae-based ethanol can offer multiple advantages compared to first and second-generation ethanol, including high areal productivity, short harvesting time, ability to grow on waste and saline water, high photoconversion efficiency, reduced need for arable land, and decreased usage of pesticides [12]. Moreover, the absence of lignin in algal carbohydrates, compared to plant biomass, facilitates their hydrolysis and subsequent fermentation, potentially decreasing the cost of bioethanol production [13]. In a recent technoeconomic analysis, ethanol production from C. vulgaris cultivated in photobioreactors (PBR) and open raceway ponds (ORP) was projected to cost $\$ 2.2$ million/year, while generating revenue of $\$ 2.9$ million/year along with additional byproduct (crude bio-oil and slurry) revenue of $\$ 1.6$ million/year [14]. Furthermore, microalgal carbohydrates can be converted to plastics, such as polyhydroxyalkanoate (PHA) and poly-lactic acid (PLA) [15]. Actually, the cyanobacteria Synechocystsis sp., Spirulina sp., Nostoc sp., and Oscillatoria sp. synthesize PHA. Moreover, microalgal carbohydrates can serve as an alternative carbon source in bacterial cultivation for bioplastic production $[15,16]$. Recently, Dunaliella tertriolecta, Nannochloropsis occulta, and Chlorella minutissima were used to produce $\beta$-galactosidase enzyme, which is utilized for hydrolysis of lactose [17].

Microalgal lipids are mainly composed of neutral triacylglycerols (TAGs) and polar structural glycolipids and phospholipids [18]. TAGs are the main energy storage compounds of microalgal metabolism and include saturated fatty acids (SFAs), monounsaturated fatty acids (MUFAs), and polyunsaturated fatty acids (PUFAs) that form the basis of producing 3rd generation biofuels (biodiesel, renewable diesel, renewable jet fuel) or nutritional supplements [19]. Microalgal PUFAs, primarily the essential fatty acids eicosapentaenoic acid (EPA; C20:5), docosahexaenoic acid (DHA; C22:6), linoleic acid (LA; C18:2), arachidonic acid (ARA; C20:4), and $\gamma$-linolenic acid (ALA; C18:3), are extensively utilized as nutraceuticals for human health [20]. On the other hand, phospholipids, such as phosphatidylcholine (PC), phosphatidyl ethanolamine (PE), lyso-phosphatidylcholine (lyso-PC), 
and phosphatidylinositol (PI), are utilized in cosmetics for the synthesis of emulsifiers, solubilizers, liposome formers, and wetting agents [21].

In addition to serving as a renewable source of proteins, carbohydrates, and lipids, microalgae have also shown potential for wastewater treatment, remediation of heavy metals and organic compounds, and production of electricity [22,23]. Wastewater treatment using microalgae has been utilized since the 1950s in high rate algal ponds (HRAPs) and has emerged as a sustainable substitute for traditional wastewater remediation [24,25]. Microalgae can utilize inorganic and organic nutrients (nitrogen, phosphorous, and carbon) for their growth and take up trace metals and heavy metals from wastewater [26,27]. Although microalgae cultivated in wastewater cannot be utilized as food or feed, their biomass can be exploited for energy production in the form of ethanol, bio-oil or biogas depending on the conversion process utilized, such as thermochemical (hydrothermal liquefaction, anaerobic digestion, pyrolysis), biochemical (fermentation), transesterification or photosynthetic microbial fuel cell (MFC) [28].

\section{The Role of Agricultural and Food Residues}

The global algal product market is projected to reach $\$ 44.7$ billion by 2023 growing at a compound annual growth rate (CAGR) of 5.4\% [8,29]. However, the current cost of production of microalgal-based products, particularly biofuels, is still not economically viable for commercial development. For successful large-scale cultivation of microalgae, abundant low-cost carbon supplies are essential, as atmospheric $\mathrm{CO}_{2}$ concentration is very low at $0.04 \%$ [30]. Moreover, although industrial flue gases can serve as external $\mathrm{CO}_{2}$ sources, they require costly infrastructure for removal of toxic components and transportation to microalgae facilities [30]. Hence, organic carbon hydrolyzed from a wide range of agricultural residues and food residues could potentially satisfy the need of microalgae cultivation for abundant, inexpensive, and preferably renewable sources of carbon [31]. The present review investigates the potential of hydrolysates derived from agricultural and food residues to support the commercial development of microalgae cultivation for sustainable production of food, fiber, fuel, feed, and fertilizer.

\subsection{Agricultural Residues as Feedstock for Microalgae}

Agricultural crop biomass, the most abundant carbon feedstock on earth, consists mainly of cellulose, hemicellulose, and lignin. The global annual production of agricultural residues from six crops (barley, maize, rice, soybean, sugar cane and wheat) is estimated at $3.7 \times 10^{9}$ tons, generating $1376 \times 10^{6}$ tons of cellulose, $848 \times 10^{6}$ tons of hemicellulose, and $666 \times 10^{6}$ tons of lignin [32]. In general, biomass is made of approximately $40-50 \%$ cellulose, $25-30 \%$ hemicellulose and $15-20 \%$ lignin in addition to minor components [33-35]. Cellulose is a linear polymer of D-glucose, hemicellulose is a branched polymer of mainly $\mathrm{D}$-xylose and L-arabinose, whereas lignin is a cross-linked polymer of phenolic compounds [35].

Given that glucose is the preferred carbon source for most microorganisms, cellulose is seen as an abundant inexpensive renewable source of glucose that can be metabolized to biofuels and value-added bioproducts by microorganisms. However, biomass first needs to be treated to render cellulose amenable to hydrolysis to glucose by the hydrolytic enzyme cellulase [36]. Overall, access to the glucose present in biomass entails the pretreatment of biomass, enzymatic hydrolysis of cellulose to glucose, and finally, fermentation of glucose by suitable microorganisms [35] to value-added products, as shown in Figure 1. 


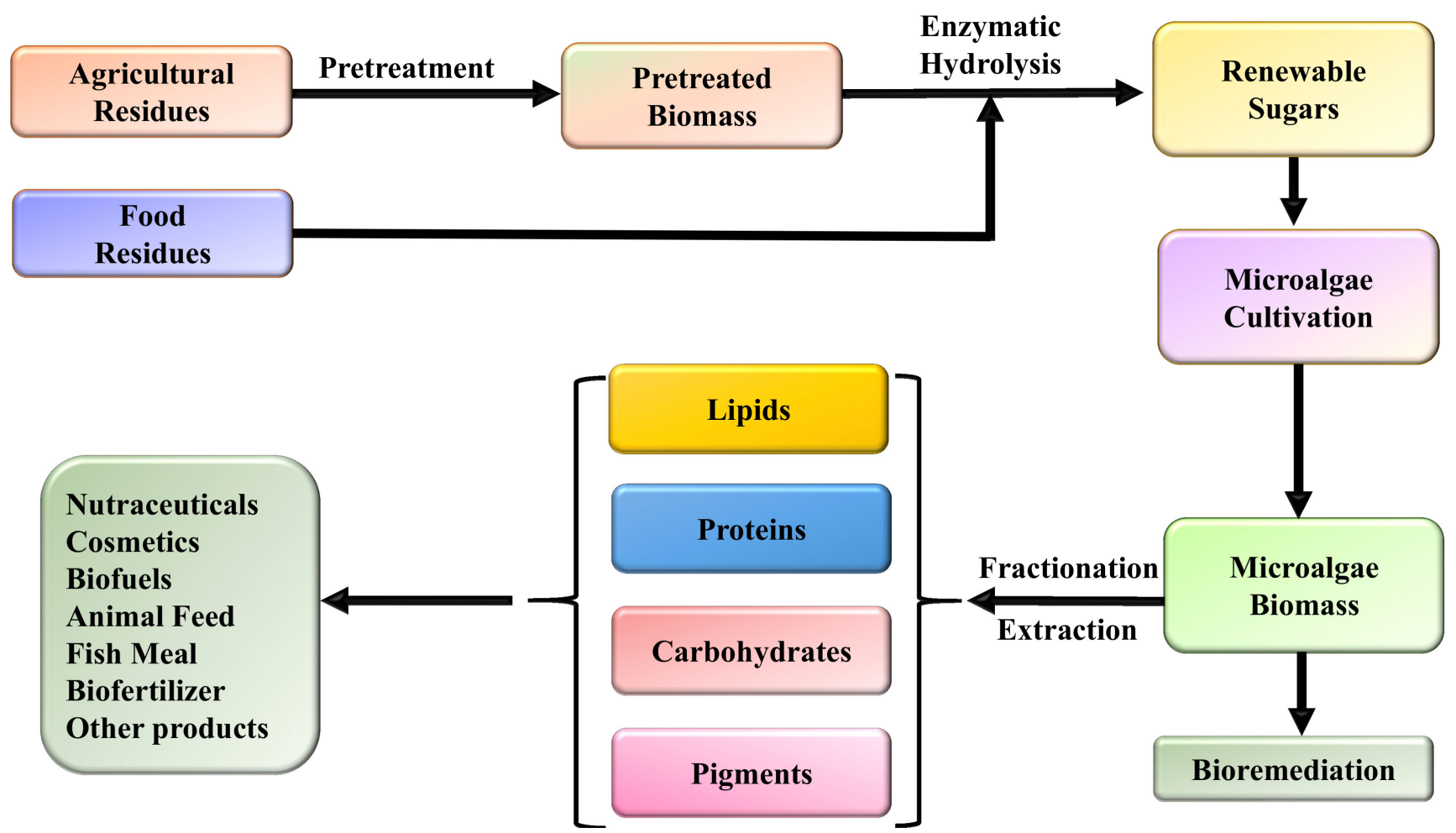

Figure 1. Schematic of biochemical conversion of agricultural and food residues to renewable sugars for algal cultivation and bioproduct production. 
Effective biomass pretreatment is pivotal for the maximum recovery of glucose and other sugars from biomass. To this end, various pretreatment methods have been developed, mainly physical, chemical, electrical, biological, and combinations [35-39]. The conversion of glucose into valuable products can be achieved through various processes, such as separate hydrolysis and fermentation (SHF), simultaneous saccharification and fermentation (SSF), simultaneous saccharification and co-fermentation (SSCF), and consolidated biomass processing (CBP) [35]. Although numerous reviews are available on biofuels and biochemicals derived from cellulosic biomass [33-35,39,40], there are no such reviews on the conversion of cellulosic residues into microalgal biomass and products.

\subsection{Food Residues as Feedstock for Microalgae}

Food residues represent the other major and inexpensive source of carbon that could be hydrolyzed and used for microalgae cultivation. Shockingly, one study estimated the annual global food residue (loss or waste) at one-third of all food generated for human consumption, an equivalent of 1.3 billion tons per year [41]. Food loss happens through the entire food supply chain. In developed countries, loss occurs mostly at the final consumption stage, while in developing countries loss takes place mostly in earlier stages such as production, processing, transportation, and storage [41,42]. In the United States in 2010 an estimated 60 million metric tons of food worth $\$ 162$ billion, equivalent to 31\% of the nation's entire food supply, was lost and wasted [43].

From a sustainability standpoint, food loss means also the loss of scarce valuable resources, especially water and fertilizers, used for producing such food. From an environmental perspective, food loss negatively impacts the environment due to greenhouse gas (methane) emissions from landfilled wasted food, worsening climate change. Thus, by reducing food loss we not only make more food available to those in need, but we also preserve natural resources and mitigate the food carbon footprint. While we strive to minimize food loss, it is prudent to make better use of food waste and prevent it from reaching the landfill. Conventional food waste management involves composting, incineration, and use as animal feed [44]. Increasingly, there is a growing interest in valorizing food waste for value-added biochemicals. In this regard, food residues represent a rich source of nutrients, especially carbon and nitrogen sources, making it a promising feedstock for potentially sustainable cost-effective production of algal and other natural products via various processes. The major challenges to valorizing food residues are their complex nature, highly variable composition, and high moisture content. In the present article, we focus on the hydrolysis of food waste into constituent sugars and subsequent conversion to microalgal biomass and products.

\section{Conversion of Low-Cost Residues to Microalgal Biomass}

\subsection{Agricultural Residues}

This section provides an overview of the numerous investigations reported in the literature of converting residues of agricultural crops into microalgal biomass and bioproducts. A summary of the range of microalgae species grown on agricultural residues, the sugar composition of each hydrolysate, the mode of microalgae cultivation, and the microalgal products is shown in Table 1. Autotrophic cultivation is conducted photosynthetically with the use of $\mathrm{CO}_{2}$ in the presence of light, heterotrophic cultivation employs organic carbon sources in the absence of light, and mixotrophic cultivation is a combination of autotrophy and heterotrophy. 
Table 1. Microalgae species cultivated on a variety of agricultural residue hydrolysates for production of microalgal bioproducts.

\begin{tabular}{|c|c|c|c|c|c|c|}
\hline Microalga & Hydrolysate & Sugar Composition & Mode of Cultivation & $\begin{array}{l}\text { Dry Cell Weight } \\
(\mathrm{g} / \mathrm{L})\end{array}$ & $\begin{array}{l}\text { Microalgal } \\
\text { Bioproduct }\end{array}$ & Reference \\
\hline \multicolumn{7}{|c|}{ Sucrose-rich agricultural residues } \\
\hline Schizochytrium limacinum & Sweet sorghum juice & $\begin{array}{c}\text { Total sugars }(242.6 \mathrm{~g} / \mathrm{L}) \text {, sucrose } \\
(142.3 \mathrm{~g} / \mathrm{L}) \text {, fructose }(61 \mathrm{~g} / \mathrm{L}) \text {, glucose } \\
(39.3 \mathrm{~g} / \mathrm{L})\end{array}$ & Heterotrophic, batch & 9.4 & Lipids + DHA & [45] \\
\hline Chlorella protothecoides & Sweet sorghum juice & $\begin{array}{c}\text { Sucrose }(101.7 \mathrm{~g} / \mathrm{L}) \text {, fructose }(33.1 \mathrm{~g} / \mathrm{L}) \text {, } \\
\text { glucose }(25 \mathrm{~g} / \mathrm{L})\end{array}$ & Heterotrophic, batch & 5.1 & Lipids & [46] \\
\hline \multicolumn{7}{|c|}{ Fructose-rich agricultural residues } \\
\hline Chlorella protothecoides & $\begin{array}{l}\text { Jerusalem artichoke } \\
\text { (Helianthus tuberosus) }\end{array}$ & Reducing sugars $(45 \mathrm{~g} / \mathrm{L})$ & Heterotrophic, batch & $16-18$ & Lipids & [47] \\
\hline Ettlia sp. & $\begin{array}{l}\text { Jerusalem artichoke } \\
\text { (Helianthus tuberosus) }\end{array}$ & $\begin{array}{c}\text { Fructose }(56 \mathrm{~g} / \mathrm{L}) \text {, glucose }(12.2 \mathrm{~g} / \mathrm{L}) \\
\text { amino acids }(7.9 \mathrm{~g} / \mathrm{L})\end{array}$ & Heterotrophic, batch & 23.6 & Lipids & {$[48]$} \\
\hline \multicolumn{7}{|c|}{ Starch-rich agricultural residues } \\
\hline Chlorella protothecoides & Corn powder & Glucose $(21.9 \mathrm{~g} / \mathrm{L})$ & Heterotrophic, batch + fed-batch & 15.5 & Lipids & [49] \\
\hline Chlorella protothecoides & Cassava starch & $\begin{array}{c}\text { Glucose }(80.7 \%), \text { maltose }(16.1 \%), \\
\text { maltotriose }(3.2 \%)\end{array}$ & Heterotrophic, batch & 15.8 & Lipids & [50] \\
\hline Chlorella protothecoides & $\begin{array}{l}\text { Cassava (Manihot esculenta) } \\
\text { starch }\end{array}$ & Reducing sugars ( $\geq 30 \mathrm{~g} / \mathrm{L}$ ) & Heterotrophic, batch + fed-batch & $49.34-53.6$ & Lipids & {$[51,52]$} \\
\hline Spirogyra sp. & Corn starch & NA & Heterotrophic, batch & 12 & Lipids & [53] \\
\hline Ankistrodesmus sp. & Corn starch & NA & Heterotrophic, batch & 1.3 & Lipids & [54] \\
\hline \multicolumn{7}{|c|}{ Sugar industry vinasse } \\
\hline Spirulina maxima & Sugar beet vinasse & NA & Mixotrophic, batch + continuous & 8 & Proteins & [55] \\
\hline Spirulina platensis & Sugar beet vinasse & NA & Mixotrophic, batch and continuous & 6.5 & Proteins & [56] \\
\hline Chlorella vulgaris & Sugarcane vinasse & NA & Mixotrophic, batch & NA & Lipids & [57] \\
\hline Scenedesmus sp. & Sugarcane vinasse & NA & Mixotrophic, batch & $0.3-0.7$ & Biomass & [58] \\
\hline Spirulina maxima & Sugarcane vinasse & NA & $\begin{array}{l}\text { Autotrophic + Heterotrophic, } \\
\text { batch + fed-batch }\end{array}$ & $0.5-0.6$ & Proteins & [59] \\
\hline $\begin{array}{l}\text { Micractinium sp. and } \\
\text { Chlamydomonas biconvexa }\end{array}$ & Sugarcane vinasse. & NA & Mixotrophic, batch & 2 & $\begin{array}{c}\text { Proteins }+ \\
\text { Carbohydrates }\end{array}$ & [60] \\
\hline
\end{tabular}


Table 1. Cont

\begin{tabular}{|c|c|c|c|c|c|c|}
\hline Microalga & Hydrolysate & Sugar Composition & Mode of Cultivation & $\begin{array}{c}\text { Dry Cell Weight } \\
(\mathrm{g} / \mathrm{L})\end{array}$ & $\begin{array}{l}\text { Microalgal } \\
\text { Bioproduct }\end{array}$ & Reference \\
\hline \multicolumn{7}{|c|}{ Lignocellulosic residues } \\
\hline $\begin{array}{l}\text { Chlorella vulgaris and Scenedesmus } \\
\text { obliquus }\end{array}$ & Wheat bran extract & Reducing sugars (54 mg/g wheat bran) & $\begin{array}{l}\text { Mixotrophic + Heterotrophic, } \\
\text { batch }\end{array}$ & $\begin{array}{l}3.4-3.7 \text { and } 3.3-5, \\
\text { respectively }\end{array}$ & $\begin{array}{c}\text { Proteins }+ \\
\text { Carbohydrates }+ \\
\text { Lipids + Pigments }\end{array}$ & [61] \\
\hline $\begin{array}{l}\text { Bacteria-microalgae consortium } \\
\text { dominated by Chlorella sp. }\end{array}$ & Corn biomass & $\begin{array}{l}\text { Reducing sugars }(55.6 \mathrm{~g} / \mathrm{L}), \text { glucose } \\
(49.9 \%) \text {, xylose }(49.9 \%)\end{array}$ & $\begin{array}{l}\text { Mixotrophic + Heterotrophic, } \\
\text { batch }\end{array}$ & $0.6-0.7$ & Biomass & [62] \\
\hline Chlorella pyrenoidosa & Rice straw & Reducing sugars $(13.7 \mathrm{~g} / \mathrm{L})$ & Mixotrophic, batch & 2.83 & Lipids & [63] \\
\hline Chlorella pyrenoidosa & Rice straw & NA & Mixotrophic, batch & 2.15 & Lipids & [64] \\
\hline Chlorella protothecoides & Rice straw & Glucose $(\sim 110 \mathrm{~g} / \mathrm{L})$ & $\begin{array}{l}\text { Mixotrophic + Heterotrophic, } \\
\text { batch }\end{array}$ & 6.5 & Lipids & [65] \\
\hline $\begin{array}{l}\text { Hawaiian species of Chlorella and } \\
\text { Scenedesmus sp. }\end{array}$ & Hardwoods & $\begin{array}{c}\text { Total sugars }(18.7,87.9,21.5,44.3 \\
27.5 \mathrm{~g} / \mathrm{L})\end{array}$ & Heterotrophic, batch & $7-8$ & Biomass & [66] \\
\hline Chlorella sorokiniana & $\begin{array}{l}\text { Beech wood (Fagus } \\
\text { sylvatica) }\end{array}$ & Glucose $(1.2 \mathrm{~g} / \mathrm{L})$, xylose $(4.7 \mathrm{~g} / \mathrm{L})$ & $\begin{array}{l}\text { Mixotrophic + Heterotrophic, } \\
\text { batch }\end{array}$ & $>0.5$ & $\begin{array}{l}\text { Biomass + Lipids + } \\
\text { Pigments }\end{array}$ & [67] \\
\hline $\begin{array}{l}\text { Chlorella sorokiniana, Chlorella } \\
\text { saccharophila, Chlorella vulgaris, } \\
\text { Coelastrella sp. }\end{array}$ & $\begin{array}{l}\text { Silver Birch wood (Betula } \\
\text { pendula) }\end{array}$ & Glucose $(61.7 \mathrm{~g} / \mathrm{L})$, xylose $(42.4 \mathrm{~g} / \mathrm{L})$ & $\begin{array}{l}\text { Mixotrophic + Heterotrophic, } \\
\text { batch }\end{array}$ & 2 & Biomass + Lipids & [68] \\
\hline Aurantiochytrium sp. & Birch wood & Glucose $(77 \mathrm{~g} / \mathrm{L})$ & Heterotrophic, batch & 11.2 & DHA + Squalene & [69] \\
\hline Chlorella protothecoides & Cassava bagasse & $\begin{array}{l}\text { Reducing sugars }(46.2 \mathrm{~g} / \mathrm{L}) \text {, glucose } \\
(34.9 \mathrm{~g} / \mathrm{L})\end{array}$ & Heterotrophic, batch + fed-batch & 9.7 & Lipids & [70] \\
\hline $\begin{array}{l}\text { Chlorella pyrenoidosa co-cultured } \\
\text { with yeast (Rhodotorula glutinis) }\end{array}$ & Cassava bagasse & Reducing sugars $(>60 \mathrm{~g} / \mathrm{L})$ & Mixotrophic, batch + fed-batch & 20.4 & Lipids & [71] \\
\hline Chlorella protothecoides & Sugarcane bagasse & $\begin{array}{c}\text { Glucose }(13.9 \mathrm{~g} / \mathrm{L}), \text { xylose }(5.3 \mathrm{~g} / \mathrm{L}) \\
\text { arabinose }(3 \mathrm{~g} / \mathrm{L})\end{array}$ & Heterotrophic, batch + fed-batch & 24 & Biomass + Lipids & [72] \\
\hline Arthrospira platensis (spirulina) & $\begin{array}{l}\text { Sugarcane bagasse } \\
\text { (untreated) }\end{array}$ & NA & Mixotrophic, batch & NA & Proteins & [73] \\
\hline Scenedesmus sp. & $\begin{array}{c}\text { Sugarcane bagasse aqueous } \\
\text { extract }\end{array}$ & $\begin{array}{c}\text { Total carbohydrates }(50 \mathrm{~g} / \mathrm{L}) \text {, sucrose } \\
(18.2 \mathrm{~g} / \mathrm{L}) \text {, glucose }(9.2 \mathrm{~g} / \mathrm{L}) \text {, fructose } \\
(8.8 \mathrm{~g} / \mathrm{L}) \text {, xylose }(4.3 \mathrm{~g} / \mathrm{L})\end{array}$ & Mixotrophic, batch & 2.2 & Lipids & [74] \\
\hline Scenedesmus dimorphus & Sugarcane bagasse & Total sugars $(>10 \mathrm{~g} / \mathrm{L})$ & Mixotrophic, batch & NA & Lipids & [75] \\
\hline Schizochytrium sp. & Sugarcane bagasse & Glucose (56.1 g/L), xylose (12.5 g/L) & Heterotrophic, batch & 10.5 & $\begin{array}{c}\text { Biomass + Lipids }+ \\
\text { DHA }\end{array}$ & [76] \\
\hline \multicolumn{7}{|c|}{ Other agricultural residues } \\
\hline Crypthecodinium cohnii & Rapeseed meal & Soluble sugars $(0.235 \mathrm{~g} / \mathrm{L})$ & Heterotrophic, batch & 3.43 & DHA & [77] \\
\hline
\end{tabular}

NA: not available. 


\subsubsection{Sucrose-Rich Agricultural Residues}

Sweet sorghum is a promising renewable feedstock valued for its enhanced tolerance to drought conditions and ability to grow in various soils and climate conditions [78,79]. Sweet sorghum residue has been widely used for the production of biofuels and value-added chemicals [80,81]. The sugar juice is obtained by squeezing or milling the stalks of the crop resulting in liquid rich mainly in sucrose, fructose, and glucose. A study reported the use of sweet sorghum juice containing $242.6 \mathrm{~g} / \mathrm{L}$ total sugars, mostly sucrose, at 25, 50, 75 and 100\% strength, to produce lipids from Schizochytrium limacinum SR21 [45]. Nearly $30 \%$ of the lipids produced by this microalga are docosahexaenoic fatty acids (DHA), which are omega-3 fatty acids popular for their beneficial health effects to human health. At the optimal strength of $50 \%$, the microalgal biomass produced from sweet sorghum juice $(9.4 \mathrm{~g} / \mathrm{L})$ was comparable to that produced from pure glucose $(10.9 \mathrm{~g} / \mathrm{L})$ and the lipid content $(73.4 \%)$ was much higher than from glucose. Total lipid and DHA production rates were faster on the juice (1.4 and $0.5 \mathrm{~g} / \mathrm{L} / \mathrm{d}$, respectively) than on glucose $(1.2$ and $0.4 \mathrm{~g} / \mathrm{L} / \mathrm{d}$, respectively). Interestingly, the microalga consumed the glucose in the juice, but not the sucrose and fructose that collectively constitute nearly $85 \%$ of the total sugars. Hence, unconsumed sucrose and fructose in the juice can still be utilized for sugar production. On the other hand, sweet sorghum juice was used to grow C. protothecoides for biodiesel production [46]. Similarly, to the previously mentioned study, C. protothecoides was also unable to utilize sucrose, which accounted for nearly $64 \%$ of total sugars in the juice. To utilize the juice sugars more efficiently, sucrose was hydrolyzed by acid and enzymatically. Compared to glucose, the enzymatic hydrolysate of sweet sorghum juice provided $37.8 \%$ higher biomass production $(5.1$ vs $3.7 \mathrm{~g} / \mathrm{L}$ ) from $10 \mathrm{~g} / \mathrm{L}$ of total sugars after $120 \mathrm{~h}$ of cultivation in shake flasks, probably thanks to the presence of other beneficial nutrients in the hydrolysate. Less biomass was produced from the acid hydrolysate than from the enzymatic hydrolysate, probably due to the formation of cell growth inhibitors during acid treatment. Although lipid content was comparable between glucose and the enzymatic hydrolysate ( 53.3 and $52.5 \%$, respectively), lipid productivity was $35.7 \%$ higher from the enzymatic hydrolysate ( 535.5 vs. $394.4 \mathrm{mg} / \mathrm{L} / \mathrm{d}$ ). Supplementing the medium with $3 \mathrm{~g} / \mathrm{L}$ of yeast extract increased biomass productivity to $1.2 \mathrm{~g} / \mathrm{L} / \mathrm{d}$ and lipid yield to $586.8 \mathrm{mg} / \mathrm{L} / \mathrm{d}$. When the lipids were derivatized by transesterification to produce biodiesel, methyl esters of palmitic (C16:0), oleic (C18:1), and linoleic (C18:2) acid were the most abundant and the quality of the resulting biodiesel was comparable to petroleum diesel.

\subsubsection{Fructose-Rich Agricultural Residues}

Jerusalem artichoke (Helianthus tuberosus) is rich in carbohydrates with 70-90\% being inulin, a linear polymer of fructose. It grows on poor lands and withstands water scarcity. Inulin is not digestible by humans but is used for diabetics on special diets to replace sugars. Researchers grew C. protothecoides in shake flasks on Jerusalem artichoke tuber hydrolysate for biodiesel production [47]. The plant's dried tubers were treated with inulinase enzyme to generate a fermentable hydrolysate containing $45 \mathrm{~g} / \mathrm{L}$ reducing sugars. A fermentation medium with $30 \mathrm{~g} / \mathrm{L}$ reducing sugars supplemented with $4 \mathrm{~g} / \mathrm{L}$ yeast extract was used. After 4 days of cultivation, C. protothecoides converted sugars into lipids and biomass at a conversion ratio of 25.2 and $57.2 \%(w / w)$, respectively, which was comparable to those from glucose at 28.2 and $62.7 \%(w / w)$, respectively. Further investigation revealed that the hydrolysate could be used on its own without yeast extract addition, thus lowering the cost and enhancing the economics of the process. Upon transesterification of lipids, C18:1, C18:2, and C16:0 methyl esters were the main components of the generated biodiesel. In a recent investigation, the microalga Ettlia sp. was cultivated on Jerusalem artichoke and lipid-extracted microalgal biomass hydrolysate as carbon and nitrogen sources, respectively [48]. Unlike most microalgae, Ettlia sp. prefers fructose over glucose under heterotrophic conditions, making Jerusalem artichoke hydrolysate an ideal substrate for this microalga. Hydrolysates were prepared by sequential dilute sulfuric acid treatment of both plant and microalgal biomass in a single process, offering potential cost savings in larger-scale operations. Fructose, glucose, and amino acid yields from the described sequential hydrolysis process 
were $0.51,0.14$ and $0.38 \mathrm{~g} / \mathrm{g}$, respectively. Biomass and lipid productivities for Ettlia sp. were 5.9 and $1.42 \mathrm{~g} / \mathrm{L} / \mathrm{d}$, respectively.

\subsubsection{Starch-Rich Agricultural Residues}

C. protothecoides has been heterotrophically cultivated on corn powder hydrolysate generated with the use of alpha-amylase and glucoamylase [49]. In shake flasks, cell concentration reached 3.92 and $3.74 \mathrm{~g} / \mathrm{L}$ on hydrolysate and glucose, respectively, and lipid content was $55.3 \%$ and $54.7 \%$, respectively, after $144 \mathrm{~h}$ cultivation. These lipid contents were nearly four times that reached under autotrophic growth (14.57\%). In fed-batch bioreactor mode, cell concentration increased to $15.5 \mathrm{~g} / \mathrm{L}$, but lipid content $(46.1 \%)$ was slightly lower than in flasks. C18:1 methyl ester formed the major fraction $(60.84 \%)$ of the biodiesel produced, which had the characteristics of high-quality diesel. Corn starch hydrolysate was used to improve biomass and lipid production from other microalgal species as well, such as Spirogyra sp. and Ankistrodesmus sp. [53,54]. After 6 weeks of heterotrophic cultivation of Spirogyra sp. using a medium supplemented with corn starch hydrolysate, the biomass and lipid content reached a maximum of $12 \mathrm{~g} / \mathrm{L}$ and $5.2 \%$, respectively [53]. Although the latter values are generally low compared to those reported for Chlorella sp., they are still significantly higher than under corresponding autotrophic cultivation $(2 \mathrm{~g} / \mathrm{L}$ and $0.5 \%$, respectively). Similarly, the biomass concentration and lipid content of Ankistrodesmus sp. increased from $0.6 \mathrm{~g} / \mathrm{L}$ and less than $10 \%$ under autotrophic conditions to $1.3 \mathrm{~g} / \mathrm{L}$ and $30 \%$, respectively, after nearly one week of heterotrophic cultivation in shake flasks using a medium supplemented with corn starch hydrolysate [54].

Cassava, another starch-rich crop, is relatively cheaper than corn and could be a low-cost source of organic carbon for heterotrophic cultivation of microalgae. C. protothecoides was cultivated on cassava starch hydrolysate [50]. A two-step enzymatic hydrolysis of cassava starch using $\alpha$-amylase and glucoamylase enzymes was better than a one-step process with a conversion efficiency of up to $97.7 \%$. The hydrolysate consisted of glucose (80.7\%), maltose (16.1\%), and maltotriose (3.2\%). After $240 \mathrm{~h}$ of cultivation in shake flasks, the biomass concentration and lipid content reached 15.8 and $4.19 \mathrm{~g} / \mathrm{L}$, respectively, from $30 \mathrm{~g} / \mathrm{L}$ hydrolysate glucose equivalents, and 10.7 and $3.3 \mathrm{~g} / \mathrm{L}$, respectively, from $40 \mathrm{~g} / \mathrm{L}$ glucose equivalents. Hence, the hydrolysate increased biomass and lipid production by $42 \%$ and $28 \%$, respectively, compared to glucose. Similarly, C. protothecoides grows better when corncob hydrolysate or cassava starch hydrolysate is used as a substitute for glucose, probably because of the presence of additional nutrients in these hydrolysates that glucose cultivation lacks [51]. Fed-batch cultivation in a 5 - $\mathrm{L}$ bioreactor using cassava starch hydrolysate ( $30 \mathrm{~g} / \mathrm{L}$ reducing sugars) and $2 \mathrm{~g} / \mathrm{L}$ yeast extract yielded $53.6 \mathrm{~g} / \mathrm{L}$ of biomass in $168 \mathrm{~h}$, equivalent to nearly $7.7 \mathrm{~g} / \mathrm{L} / \mathrm{d}$, compared to $51.2 \mathrm{~g} / \mathrm{L}$ and $7.3 \mathrm{~g} / \mathrm{L} / \mathrm{d}$ using solely glucose. Moreover, the oil content and yield reached $53 \%$ and $28.4 \mathrm{~g} / \mathrm{L}$ compared to $50.3 \%$ and $25.8 \mathrm{~g} / \mathrm{L}$ in glucose, respectively. The biodiesel produced by transesterification was similar to that of glucose with nearly $90 \%$ of the biodiesel consisting of methyl esters of the fatty acids C16:0, C18:2, and C18:1. In a follow-up study by the same group, simultaneous saccharification and heterotrophic microalgal fermentation approaches were employed to simplify the multistep separate saccharification and fermentation approach used earlier [52]. The biomass concentration and the simplicity provided by such a process integration make the simultaneous approach promising for large-scale cultivation of microalgae using cassava starch and other feedstocks that can be processed similarly.

\subsubsection{Sugar Industry Vinasse}

Vinasse is a liquid byproduct of the sugar-ethanol industry that is difficult to dispose of and is considered an environmental burden. It is a dark, acidic, and rich in biodegradable organic nutrients liquid that has been tested for the cultivation of microalgae. It also contains high concentrations of phenolic compounds known to negatively impact the growth of microalgae, hence necessitating processing steps to mitigate such toxicity [82]. Spirulina maxima, a microalga known for accumulating high levels of protein edible by humans and animals, was grown on vinasse obtained from sugar beet molasses fermentation [55]. In shake flasks, S. maxima was able to grow in Schlosser media 
supplemented with up to $5 \mathrm{~g} / \mathrm{L}$ of vinasse. However, higher concentrations of vinasse inhibited cell growth, probably due to its dark color that prevents light penetration or the presence of growth inhibitors. In a tubular photobioreactor, biomass concentration and productivity reached 3.5-4.8 g/L and $0.15-0.24 \mathrm{~g} / \mathrm{L} / \mathrm{d}$, respectively, under batch operation mode. The biomass concentration and productivity were further enhanced to $8 \mathrm{~g} / \mathrm{L}$ and $0.7 \mathrm{~g} / \mathrm{L} / \mathrm{d}$, respectively, when the photobioreactor was run in continuous operation mode using a medium supplemented with $2 \mathrm{~g} / \mathrm{L}$ vinasse. Notably, betaine, an organic nitrogenous compound found in vinasse, was completely consumed during microalgal cultivation, indicating that vinasse serves as both a carbon and nitrogen source. In another study from the same group using Spirulina platensis, supplementing the medium with $1 \mathrm{~g} / \mathrm{L}$ vinasse resulted in significant improvement in biomass concentration and protein productivity $(6.5 \mathrm{~g} / \mathrm{L}$ and $0.17 \mathrm{~g} / \mathrm{L} / \mathrm{d}$, respectively) [56]. In that study, cultivation was carried out in a tubular photobioreactor operated under continuous operation mode for 160 days with a retention time of 20 days.

When sugarcane vinasse was used to grow $C$. vulgaris, it was observed that unfermented vinasse was highly toxic at concentrations above $4 \%$ [57]. On the other hand, anaerobically fermented vinasse was less toxic to microalgal cells, enabling the utilization of higher vinasse concentrations. When the microalgal growth medium was supplemented with $8.6 \%$ of fermented vinasse, a specific growth rate of $0.76 / \mathrm{d}$ was achieved compared to $0.10 / \mathrm{d}$ with non-fermented vinasse. These observations indicate that anaerobic digestion mitigated the viscosity and overall toxicity of vinasse. In another study, a factorial design and central composite design were conducted to evaluate the feasibility of using sugarcane vinasse for cultivating Scenedesmus sp. in an airlift photobioreactor [58]. Both designs revealed that light intensity contributed positively to biomass production and that increasing vinasse concentration affected growth negatively. The temperature effect was insignificant, indicating that Scenedesmus sp. could be grown at any temperature within the predetermined temperature range $\left(20-35^{\circ} \mathrm{C}\right)$, as long as vinasse concentration was kept below $40 \%$. Another study employed cyclic two-stage cultivation (CTSC) for S. maxima in which the microalga was cultivated in two alternating phases: autotrophically in the presence of light for $12 \mathrm{~h}$ and then heterotrophically in the dark for $12 \mathrm{~h} \mathrm{[59].} \mathrm{The} \mathrm{study} \mathrm{revealed} \mathrm{that} \mathrm{synergy} \mathrm{existed} \mathrm{between} \mathrm{light} \mathrm{and} \mathrm{vinasse} \mathrm{to} \mathrm{enhance}$ growth. Moreover, CTSC can be advantageous in enhancing biomass productivity without adversely affecting protein content. Employing CTSC, biomass concentration reached $0.495-0.609 \mathrm{~g} / \mathrm{L}$ on the 7 th day of each cycle, while maintaining high protein content of $74.3-77.3 \% w / w$. Another study screened forty microalgae strains for growth on various concentrations of sugarcane vinasse [60]. Two strains, Micractinium sp. and Chlamydomonas biconvexa, exhibited robust growth in the presence of light and under non-axenic conditions. Biomass productivity $(164.4-222.2 \mathrm{mg} / \mathrm{L} / \mathrm{d})$ and protein content (39.5-41.7\%) were both enhanced in the presence of vinasse compared to the standard Bold's Basal Medium (BBM) (101.1-132.2 mg/L/d and 30.1-34\%, respectively), using 15-L airlift flat plate photobioreactors. The two strains accumulated mostly glucose-based carbohydrates as the second major biomass component after proteins. Interestingly, vinasse caused a shift in the carbohydrate profile towards galactose-based carbohydrates at the expense of glucose-based carbohydrates. Based on the reported results, those strains hold promise in terms of enhanced biomass productivity and protein and carbohydrate production by microalgae from vinasse.

\subsubsection{Lignocellulosic Residues}

As mentioned earlier, lignocellulosic biomass is the most abundant carbon source on earth and it is generally inexpensive, rendering it a promising raw material for the biosynthesis of multitudes of value-added products, including microalgal ones. It comprises mainly cellulose, hemicellulose, and lignin. Numerous types of lignocellulosic biomass with various characteristics can serve this purpose, including agricultural biomass, like sugarcane bagasse, sweet sorghum bagasse, corn biomass, and rice straw, and forestry biomass from hardwood and softwood trees. Wheat bran is a lignocellulosic residue that is widely disposed of by burning, raising environmental concerns. Because of its high lignin and silica content, low protein content, and poor digestibility, it is not suitable for animal feed. On the other 
hand, it is used in the food industry as dietary fiber in fiber-enriched foods. Wheat bran was provided to two fungi (Pleurotus ostreatus, Trichoderma viride) to degrade lignin and release its content of reducing sugars into a water-soluble extract [61]. The aqueous extract was then used at various concentrations $(0.25-1.5 \% \mathrm{v} / \mathrm{v})$ to grow the microalgae; C. vulgaris and Scenedesmus obliquus under mixotrophic and heterotrophic conditions. C. vulgaris reached a concentration of nearly 3.7 and $3.4 \mathrm{~g} / \mathrm{L}$ on the extract compared to 4 and $3.2 \mathrm{~g} / \mathrm{L}$ on glucose, under mixotrophic and heterotrophic conditions, respectively. S. obliquus reached a concentration of 3.3 and $5 \mathrm{~g} / \mathrm{L}$ on the extract compared to 4 and $4.4 \mathrm{~g} / \mathrm{L}$ on glucose, under mixotrophic and heterotrophic conditions, respectively. The carbohydrate and protein content of both microalgae increased with increasing extract concentration under mixotrophic conditions. The aqueous extract improved lipid production in mixotrophic cultures and had no significant effect in heterotrophic cultures of either microalga. Overall, the effect of the water-soluble extract of wheat bran was comparable to that of glucose under both mixotrophic and heterotrophic conditions, yet it is much cheaper and potentially more economic as a carbon source.

Corn biomass hydrolysate (mostly glucose and xylose with traces of arabinose) and silage juice (mostly acetic, lactic, propionic, butyric, succinic, and citric acid) were used for cultivation of and lipid production from a bacteria-microalgae consortium dominated by Chlorella sp. [62]. Silage is generated in large quantities by natural anaerobic fermentation that takes place during the storage of crops in silos and is considered an environmental pollutant. The study indicated that corn silage is not a potential alternative carbon source for growing microalgae due to its inherent toxicity and failure to support high levels of lipid production. On the other hand, residual corn hydrolysate enhanced microalgal biomass production by 4-fold compared to phototrophic cultivation. Compared to glucose, biomass production was enhanced by $21 \%$ and $11 \%$ under mixotrophic and heterotrophic conditions, respectively, which could probably be explained by the presence of additional nutrients in the hydrolysate. Statistical analysis revealed a significant interaction between cultivation time and cultivation mode and between cultivation time and the nature of organic carbon utilized. However, the hydrolysate reduced the lipid content to 15 and $7 \%$ in mixotrophic and heterotrophic modes, respectively, compared to $30 \%$ in phototrophic mode. In addition, the relative composition of fatty acids changed on residual corn hydrolysate compared to phototrophic cultivation and the corresponding FAMEs did not satisfy the required properties for biodiesel production. Overall, residual corn hydrolysate might still be a potential low-cost alternative to glucose especially in applications aiming at enhancing algal biomass production, although optimization of the cultivation media is still needed to enhance lipid production as well.

Rice straw is an abundant byproduct of rice production as millions of tons are generated annually especially in Asia. Farmers usually dispose of rice straw by burning it, which contributes to air pollution and greenhouse gases emissions. Hence, there has been growing interest in valorizing rice straw using environmentally friendly approaches. In this context, rice straw hydrolysate, prepared by pretreatment of rice straw with trifluoroacetic acid and subsequent hydrolysis with commercial cellulase, was used as feedstock for producing biodiesel from C. pyrenoidosa [63]. In shake flasks, microalgal biomass reached a 3-fold higher concentration and was produced at a 3.3-fold higher rate in rice straw hydrolysate than in glucose $(2.83 \mathrm{~g} / \mathrm{L}$ and $1.1 \mathrm{~g} / \mathrm{L} / \mathrm{d}$ compared to $0.92 \mathrm{~g} / \mathrm{L}$ and $0.37 \mathrm{~g} / \mathrm{L} / \mathrm{d}$, respectively) within $48 \mathrm{~h}$. Similarly, lipid content and productivity were both enhanced in hydrolysate vs glucose $(56.3 \%$ and $0.62 \mathrm{~g} / \mathrm{L} / \mathrm{d}$ compared to $50.3 \%$ and $0.19 \mathrm{~g} / \mathrm{L} / \mathrm{d}$, respectively). These results strongly indicate that rice straw hydrolysate contains substances that stimulate cell growth and oil biosynthesis. To save cost and increase biodiesel yield, researchers applied in-situ transesterification of the algal biomass, eliminating the need for lipid extraction. The biomass-to-FAMEs conversion efficiency was 95.7\%, and the dominant FAMEs (98\%) were those of C16:0, C18:0, and C18:2, an indication of high-quality biodiesel. Hence, the investigation demonstrated that rice straw hydrolysate is a promising feedstock for enhancing biodiesel production from C. pyrenoidosa. In another investigation involving in-situ transesterification, rice straw hydrolysate in combination with dairy wastewater supported the growth C. pyrenoidosa, and the biodiesel produced demonstrated better engine performance and emissions 
profile compared to petroleum diesel [64]. In yet another investigation, a method for pretreatment of rice straw hydrolysate with gamma irradiation and alkali solution was developed [65]. The hydrolysate was then used to cultivate C. protothecoides for lipid production, but under both heterotrophic and mixotrophic conditions rice straw hydrolysate resulted in lower biomass production compared to glucose ( 6.5 and $4 \mathrm{~g} / \mathrm{L}$ compared to 8.7 and $6 \mathrm{~g} / \mathrm{L}$, respectively). No significant difference was observed in the total lipid content of the microalgae cells (around 55\%) and in the fatty acid composition between the hydrolysate and glucose cultures under both modes of cultivations.

The wood industry generates large quantities of residue that is treated as waste. The woody nature of such residues means it is made up of cellulosic biomass, which can be upgraded to more valuable products. In this regard, the use of various wood residue hydrolysates for heterotrophic cultivation of Hawaiian species of Chlorella and Scenedesmus in bioreactors was assessed. The initial total sugar concentration in all tested woody hydrolysates (Southern Hardwood Chips, Southern Pine Bleached Kraft and Southern Pine Finer Chips) was set at $18 \mathrm{~g} / \mathrm{L}$ [66]. All of them supported microalgal growth, but to different extents. Notably, Southern Pine Finer Chips inhibited cell growth, but when diluted to $9 \mathrm{~g} / \mathrm{L}$ of total sugars it supported better growth than glucose. All woody hydrolysates also led to better growth compared to pure sugars (glucose and xylose). For example, 2.87 and $1.7 \mathrm{~g} / \mathrm{L} / \mathrm{d}$ biomass productivities were reported for Chlorella sp. grown with Bleached Southern Pine hydrolysate. The tested Chlorella and Scenedesmus strains were able to utilize both glucose and xylose. In another study, neutralized dilute acid hydrolysate of beech wood (Fagus sylvatica) was used to support the production of microalgal biomass, fatty acids, and pigments by Chlorella sorokiniana in a multi-tube photobioreactor [67]. The hydrolysate consisted mainly of xylose, and 12\% hydrolysate enhanced production under mixotrophic and heterotrophic compared to autotrophic conditions. More recently, a combination of birch wood hydrolysate (Betula pendula) and dairy effluent was tested for growing various microalgae strains (C. sorokiniana, Chlorella saccharophila, C. vulgaris, and Coelastrella sp.) under mixotrophic and two-stage mixotrophic/heterotrophic modes [68]. Coelastrella sp. was able to grow on the mixture without the need to use additional nutrients (nitrogen, phosphorous, potassium), whereas other microalgae required supplementation of these nutrients. In general, the absence of additional supplements enhanced lipid production up to $40 \%$, although biomass production was lower. In all tested microalgae, C16:0, C18:1 and C18:2 were the dominant FAMEs produced after transesterification. Birchwood hydrolysate supplemented with yeast extract as nitrogen source has also been tested for producing docosahexaenoic acid (DHA) and squalene by Aurantiochytrium sp. in flasks and a bioreactor [69]. DHA is well known for its health benefits and squalene can be used for the synthesis of sterols and the manufacture of high-quality jet biofuel. Biomass, total lipids, DHA fraction of total lipids, and squalene concentration were significantly higher in the bioreactor than in the flasks reaching $11.2 \mathrm{~g} / \mathrm{L}, 5.9 \mathrm{~g} / \mathrm{L}, 35.8 \%$ and $1 \mathrm{~g} / \mathrm{L}$, respectively. Similarly, biomass and lipid productivities in the bioreactor ( 3.7 and $2 \mathrm{~g} / \mathrm{L} / \mathrm{d}$, respectively) surpassed those in flasks ( 2.6 and $1.25 \mathrm{~g} / \mathrm{L} / \mathrm{d}$, respectively). DHA was produced at a rate of $703 \mathrm{mg} / \mathrm{L} / \mathrm{d}$ and the corresponding squalene yield was $88.5 \mathrm{mg} / \mathrm{g}$ dry cell weight. These results suggest that woody hydrolysates can serve as a low-cost carbon source for the production of valuable nutraceuticals.

Bagasses are another group of cellulosic residues that are increasingly used as renewable sources of fermentable sugars. Cassava bagasse is a byproduct of the cassava starch extraction process that contains high levels of starch in addition to typical cellulosic polymers. Cassava bagasse hydrolysate generated via enzymatic hydrolysis was used in batch cultivation of C. protothecoides [70]. The hydrolysate resulted in comparable biomass and fatty acids yields as glucose, but with higher productivity. In fed-batch mode, biomass concentration increased, but the biomass and fatty acids yields did not change, compared to batch cultivation. Biomass concentration and yield of $9.7 \mathrm{~g} / \mathrm{L}$ and $0.28 \mathrm{~g} / \mathrm{g}$, respectively, fatty acid concentration, content, and yield of $5.8 \mathrm{~g} / \mathrm{L}, 41 \%, 0.21 \mathrm{~g} / \mathrm{g}$ sugar, respectively, and total neutral lipid content of $58.4 \%$, were achieved in fed-batch runs with cassava bagasse hydrolysate. In a follow up paper from the same group, non-detoxified direct cellulase hydrolysate of cassava bagasse was employed to produce oil in a mixed culture of C. pyrenoidosa and the oleaginous yeast Rhodotorula 
glutinis at an initial microalgae-to-yeast mass ratio of 3:1 [71]. Cell biomass concentration in the mixed culture was generally higher than in individual cultures. Moreover, cell biomass concentration was generally higher in the hydrolysate compared to glucose reaching $20.4 \mathrm{~g} / \mathrm{L}$. Similarly, lipid production was better in the mixed culture compared to individual cultures with total lipids, lipid productivity, and maximum lipid content reaching $10.4 \mathrm{~g} / \mathrm{L}, 868 \mathrm{mg} / \mathrm{L} / \mathrm{d}$ and $53.2 \%$, respectively. Fatty acid concentration and productivity reached nearly $9 \mathrm{~g} / \mathrm{L}$ and $750 \mathrm{mg} / \mathrm{L} / \mathrm{d}$, respectively. Under fed-batch cultivation, the final biomass and lipid concentrations reached nearly 31.5 and $18.5 \mathrm{~g} / \mathrm{L}$, respectively, higher than respective values for batch cultivation.

Sugarcane bagasse is the main byproduct of the sugarcane industry and, like cassava bagasse, it can be converted into fermentable sugars via chemical or enzymatic processing. Sugarcane bagasse hydrolysate (SBH) as a low-cost feedstock for algal biomass and lipid production was tested on C. protothecoides under heterotrophic growth conditions in flasks [72]. The hydrolysate was prepared using cellulase and $\beta$-glucosidase enzymes. Compared to glucose and an artificial mixture of sugars (AMS) that mirrored the hydrolysate main sugars, SBH in batch mode displayed better algal biomass and lipid production as it yielded biomass that was 2.48- and 1.37-fold higher than from glucose and AMS, respectively. Lipid content increased by 58.1 and $9.7 \%$, and lipid productivity was $4.9-$ and 1.9-fold higher than from glucose and AMS, respectively. Taken together, these results indicate the presence of beneficial factors in SBH, which positively influence growth and lipid accumulation in C. protothecoides. In fed-batch mode, the maximum algal biomass and productivity were much higher than in batch cultures, reaching nearly $24 \mathrm{~g} / \mathrm{L}$ and $1.8 \mathrm{~g} / \mathrm{L} / \mathrm{d}$, respectively. Lipid productivity in fed-batch was 3 times that of batch mode, reaching $1.2 \mathrm{~g} / \mathrm{L} / \mathrm{d}$. Overall sugar utilization reached $82 \%$ and biomass yield was approximately $0.41 \mathrm{~g} / \mathrm{g}$ sugar, which are comparable to or higher than yields reported for similar hydrolysates. In another study, sugarcane bagasse aqueous extract (SBAE) was used for the cultivation of a novel freshwater microalgae isolate, Scenedesmus sp. IITRIND2 [74]. SBAE proved non-toxic to the tested microalga and could be used at its full strength $(100 \%)$, one more advantage in addition to the simplicity of its preparation and the inherent low-cost of sugarcane bagasse compared to commercial sugars. Microalgal biomass concentration of $2.2 \mathrm{~g} / \mathrm{L}$ was attained in $100 \%$ SBAE. Biomass productivity of $213 \mathrm{mg} / \mathrm{L} / \mathrm{d}$ was much higher than the respective phototrophic control in BBM media and BBM media supplemented with glucose ( 150 and $100 \mathrm{mg} / \mathrm{L} / \mathrm{d}$, respectively). It is believed that the presence of various sugars and trace elements in SBAE contributed to enhanced growth. Scanning electron microscope (SEM) images showed no change in the morphology of SBAE-grown cell, but cell size increased, probably due to the accumulation of more lipids. Lipid content reached $52.6 \%$ in $100 \%$ SBAE, which is 1.9-fold higher than in BBM and 1.5-fold higher than in BBM supplemented with glucose. Lipid productivity reached $112 \mathrm{mg} / \mathrm{L} / \mathrm{d}$ in 100\% SBAE. On the other hand, carbohydrate content slightly decreased from $100 \% \mathrm{SBAE}$, likely because more carbon flux was directed towards lipid biosynthesis. The highest carbohydrate content of 36.5\% was achieved in $75 \%$ SBAE, which corresponded to $18.35 \%$ protein content. The FAMEs profile complied with ASTM D6751 and EN14214 fuel standards, indicating high-quality biodiesel. C16:0, C18:2 and C18:1 acid comprised the major fractions of fatty acids. Interestingly, the relative proportion of fatty acids varied with varying SBAE strength (25 to $100 \%)$. Better microalgal biomass and lipid accumulation was similarly reported when SBH was utilized for heterotrophic cultivation of Schizochytrium sp. compared to refined glucose [76]. In that study, sugarcane bagasse was treated with alkali to remove lignin prior to treatment with phosphoric acid to dissolve hemicellulose followed by enzymatic hydrolysis with cellulase. Microalgal biomass concentration reached $10.5 \mathrm{~g} / \mathrm{L}$ with $40 \mathrm{~g} / \mathrm{L} \mathrm{SBH}$ glucose indicating that SBH contains additional factors favorable for microalgal growth, as also reported by other researchers. Lipid content reached $45 \%$ at $40 \mathrm{~g} / \mathrm{L} \mathrm{SBH}$ glucose and was slightly higher than the corresponding lipid content with glucose. Considering the low cost of sugarcane bagasse and the high biomass concentration and lipid yield that can be achieved at $40 \mathrm{~g} / \mathrm{L} \mathrm{SBH}$ glucose, DHA and PUFA could potentially be produced cost-effectively via microalgae cultivation in SBH. In a recent study, SBH was used for mixotrophic batch cultivation of Scenedesmus dimorphus NT8c in shake flasks [75]. This microalgae strain was selected because of its heat 
tolerance and rapid growth capabilities and the feasibility of harvesting biomass by simple overnight settling. Supplementing BBM medium with $5 \mathrm{~g} / \mathrm{L} \mathrm{SBH}$ was generally better than phototrophic growth, but supplementing BBM with $10 \mathrm{~g} / \mathrm{L}$ SBH sugars was not favorable because the darker medium color reduced light penetration, consequently suppressing microalgal growth. In mixotrophic mode, biomass productivity and protein content $(120 \mathrm{mg} / \mathrm{L} / \mathrm{d}$ and $34 \%$, respectively) in SBH were higher than the respective phototrophic levels $(96 \mathrm{mg} / \mathrm{L} / \mathrm{d}$ and $29.6 \%$, respectively). Moreover, higher levels of C14:0, C16:0, C18:0 and C22:0 fatty acids were detected in SBH cultures compared to phototrophic cultures. Interestingly, C20:0 fatty acids (omega-3) were only detected in the SBH mixotrophic cultures, whereas carotenoid pigments and chlorophyll a and b pigments were generally lower in SBH cultures compared to phototrophic cultures.

There are a few studies that examined the application of solid-state fermentation for the cultivation of microalgae. The use of sugarcane bagasse in solid-state fermentation for protein production by Arthrospira platensis (spirulina) was investigated [73]. Results indicated that the moisture content had a strong effect on process performance. The optimal conditions for protein production were $98.8 \%$ moisture, $0.15 \mathrm{~g}$ starting (inoculum) biomass concentration, and $6 \mathrm{klx}$ light intensity. However, such high moisture content raises questions as to whether microalgae can be cultivated in truly solid-state conditions, so more research is necessary for this area.

\subsubsection{Other Agricultural Residues}

DHA production by Crypthecodinium cohnii was studied with the low-cost feedstocks of rapeseed meal hydrolysate and waste molasses as nitrogen and carbon sources, respectively [77]. Rapeseed meal is the residue remaining after oil extraction from the seeds. The meal is rich in nutrients, such as protein, fat, fiber, pectin, and minerals. Nonetheless, many industrial microorganisms cannot grow on rapeseed meal as feedstock. To make the meal nutrients more amenable for microbial consumption, the meal was treated with solid-state fungal fermentation followed by fungal autolysis (enzymatic hydrolysis). Not only did this treatment increase the free amino acids and soluble sugar content of the meal, but it also reduced its content of inhibitory components. As a result, minimal medium supplemented with diluted rapeseed meal hydrolysate supported the growth of $C$. cohnii and other oleaginous organisms, but biomass concentration was relatively low compared to the rich YPD medium commonly used for growing such microorganisms. No further increase in biomass was achieved by adding yeast extract to the hydrolysate, indicating that the hydrolysate was rich enough in nitrogen already. Therefore, more carbon was needed to raise the $\mathrm{C} / \mathrm{N}$ ratio, which is critical for oil production in oleaginous organisms. Supplementing the hydrolysate with molasses, a byproduct of the sugar industry rich in inorganic elements, enhanced both the biomass and DHA yield of C. cohnii. In shake flasks, a medium containing 7\% rapeseed meal hydrolysate and 1-9\% molasses yielded maximum biomass and DHA concentrations of $3.43 \mathrm{~g} / \mathrm{L}$ and $8.72 \mathrm{mg} / \mathrm{L}$, respectively, with DHA accounting for $22-34 \%$ of the total fatty acids produced.

\subsection{Food Residues}

\subsubsection{Food Waste}

Food waste constitutes one of the major sources (22\%) of municipal solid waste reaching landfills and combustion facilities [83]. Food waste primarily comprises cereals (30\%), root crops, vegetables, fruits (40-50\%), oilseeds (20\%), and meat and dairy (35\%) [84]. Hence, food waste consists of starch (30-60\%), proteins (5-10\%), and lipids (10-40\%), although the composition varies depending on the sources [83]. These macromolecules can be hydrolyzed and broken down into simple molecules, which can then be utilized as a carbon source for cultivating microalgae [85]. To this end, various studies have reported utilization of food waste hydrolysate $(\mathrm{FWH})$ as a cultivation medium for a wide range of microalgae strains (Table 2). 
Table 2. Microalgal species cultivated on a variety of food residue hydrolysates for production of microalgal bioproducts.

\begin{tabular}{|c|c|c|c|c|c|c|}
\hline Microalga & Hydrolysate & Sugar Composition & Mode of Cultivation & $\begin{array}{l}\text { Microalgal } \\
\text { Bioproduct }\end{array}$ & $\begin{array}{c}\text { Dry Cell Weight } \\
(\mathrm{g} / \mathrm{L})\end{array}$ & Reference \\
\hline \multicolumn{7}{|c|}{ Food waste } \\
\hline \multirow{2}{*}{ Chlorella vulgaris } & \multirow{11}{*}{ Food waste } & Total carbon $(30.84 \%)$ & \multirow{3}{*}{ Mixotrophic, batch } & Lipids & 1.72 & [86] \\
\hline & & NA & & Bioelectricity + lipids & 1.2 & [87] \\
\hline \multirow{3}{*}{ Chlorella pyrenoidosa } & & Glucose (5 g/L) & & $\begin{array}{l}\text { Lactic acid }+ \\
\text { plasticizer }\end{array}$ & - & [83] \\
\hline & & Total carbon $(20 \mathrm{~g} / \mathrm{L})$ & Heterotrophic, batch & \multirow{2}{*}{$\begin{array}{l}\text { Lipids + proteins }+ \\
\text { carbohydrates }\end{array}$} & 10 & [88] \\
\hline & & Glucose $(17 \mathrm{~g} / \mathrm{L})$, fructose $(0.6 \mathrm{~g} / \mathrm{L})$ & Heterotrophic, continuous & & 25 & [89] \\
\hline Chlorella sp. & & Total carbon $(495 \mathrm{mg} / \mathrm{g})$ & Mixotrophic, semi-continuous & Lipids + Lutein & 6.9 & [84] \\
\hline Auxenochlorella protothecoides & & Glucose $(20 \mathrm{~g} / \mathrm{L})$, fructose $(6.10 \mathrm{~g} / \mathrm{L})$ & \multirow{2}{*}{ Heterotrophic, batch } & Lipids & 9.02 & [90] \\
\hline Chlorella sorokinana & & Glucose $(42 \mathrm{~g} / \mathrm{L})$, fructose $(10 \mathrm{~g} / \mathrm{L})$ & & Proteins & 9.5 & [91] \\
\hline \multirow{2}{*}{ Phaeodactylum tricornutum } & & NA & \multirow{2}{*}{ Mixotrophic, batch } & \multirow{2}{*}{ PUFA } & - & \multirow{2}{*}{ [92] } \\
\hline & & Glucose $(245.5 \mathrm{~g} / \mathrm{L})$ & & & 0.50 & \\
\hline Aurantiochytrium sp. T66 & & Glucose $(78.34 \mathrm{~g} / \mathrm{L})$, fructose $(24.96 \mathrm{~g} / \mathrm{L})$ & Heterotrophic, batch & DHA + squalene & 14.7 & [93] \\
\hline Golenkinia sp. & $\begin{array}{l}\text { Anaerobically digested } \\
\text { food waste }\end{array}$ & NA & Mixotrophic, batch & $\begin{array}{c}\text { Bioelectricity }+ \\
\text { Biogas + Lipids }\end{array}$ & 0.8 & [94] \\
\hline \multirow{2}{*}{ Galdieria sulphuraria } & Restaurant waste & $\begin{array}{l}\text { Glucose }(103 \mathrm{~g} / \mathrm{L}) \text {, sucrose }(6 \mathrm{~g} / \mathrm{L}) \text {, } \\
\text { fructose }(13 \mathrm{~g} / \mathrm{L}), \text { xylose }(14 \mathrm{~g} / \mathrm{L})\end{array}$ & \multirow[t]{2}{*}{ Heterotrophic, batch } & \multirow{6}{*}{ Lipids } & $0.65 \mathrm{~g} / \mathrm{g}$ glucose & \multirow[t]{2}{*}{ [85] } \\
\hline & Bakery waste & $\begin{array}{l}\text { Glucose }(128 \mathrm{~g} / \mathrm{L}) \text {, sucrose }(72 \mathrm{~g} / \mathrm{L}) \\
\text { fructose }(6 \mathrm{~g} / \mathrm{L})\end{array}$ & & & $0.72 \mathrm{~g} / \mathrm{g}$ glucose & \\
\hline Chlorella sorokinana & \multirow{4}{*}{$\begin{array}{l}\text { Anaerobically digested } \\
\text { kitchen waste }\end{array}$} & \multirow{2}{*}{ Total organic carbon $(3.761 \mathrm{~g} / \mathrm{L})$} & \multirow{6}{*}{ Mixotrophic, batch } & & 0.42 & \multirow{2}{*}{ [95] } \\
\hline Scenedesmus sp. & & & & & 0.55 & \\
\hline Chlorella sp. & & \multirow{4}{*}{ NA } & & & 0.53 & \multirow{2}{*}{ [96] } \\
\hline Scenedesmus sp. & & & & & 0.52 & \\
\hline Chlorella vulgaris & \multirow{2}{*}{ Okara waste } & & & \multirow{2}{*}{$\begin{array}{c}\text { Lipids + } \\
\text { carbohydrates }\end{array}$} & 1.92 & \multirow{2}{*}{ [97] } \\
\hline Nannochloropsis oculata & & & & & 1 & \\
\hline
\end{tabular}


Table 2. Cont.

\begin{tabular}{|c|c|c|c|c|c|c|}
\hline Microalga & Hydrolysate & Sugar Composition & Mode of Cultivation & $\begin{array}{l}\text { Microalgal } \\
\text { Bioproduct }\end{array}$ & $\begin{array}{c}\text { Dry Cell Weight } \\
(\mathrm{g} / \mathrm{L})\end{array}$ & Reference \\
\hline \multicolumn{7}{|c|}{ Fruit waste } \\
\hline Chlorella vulgaris & Fruit waste & Total reducing sugar $(43.6 \mathrm{~g} / \mathrm{L})$ & Mixotrophic, batch & Lipids & - & [98] \\
\hline \multirow{3}{*}{ Aurantiochytrium sp. } & $\begin{array}{l}\text { Musa acuminate colla } \\
\text { (Banana) }\end{array}$ & Total sugar content $(0.72 \mathrm{~g} / \mathrm{g})$ & \multirow{2}{*}{ Mixotrophic, fed-batch } & \multirow{3}{*}{ DHA } & 13 & [99] \\
\hline & $\begin{array}{l}\text { Ananas comosus MD2 } \\
\text { (Pineapples) }\end{array}$ & Total sugar content $(0.70 \mathrm{~g} / \mathrm{g})$ & & & 12 & \\
\hline & \multirow{2}{*}{ Orange peel extract } & $\begin{array}{c}\text { Glucose }(5.1-5.9 \mathrm{~g} / \mathrm{L}), \text { fructose } \\
(5.1-5.6 \mathrm{~g} / \mathrm{L})\end{array}$ & Heterotrophic, batch & & 4 & {$[100]$} \\
\hline Chlorella vulgaris & & Glucose $(4.2 \mathrm{~g} / \mathrm{L})$, sucrose $(2.7 \mathrm{~g} / \mathrm{L}$ & Mixotrophic, batch & \multirow{3}{*}{ Lipids } & 2.20 & [101] \\
\hline Chlorella protothecoides & Papaya waste & Total sugar $(101 \mathrm{~g} / \mathrm{Kg})$ & Heterotrophic, batch & & $34.76 \mathrm{~g} / \mathrm{Kg}$ & [102] \\
\hline Tetraselmis indica & Kinnow peel waste & $\mathrm{NA}$ & \multirow{2}{*}{ Mixotrophic, batch } & & 0.98 & [103] \\
\hline Crypthecodinium cohnii & Date syrup & $\begin{array}{l}\text { Glucose }(37 \%) \text {, fructose }(43 \%) \text {, sucrose } \\
(3 \%)\end{array}$ & & DHA & 42 & [104] \\
\hline \multicolumn{7}{|c|}{ Dairy waste } \\
\hline \multirow{3}{*}{ Chlorella vulgaris } & \multirow{10}{*}{ Cheese whey } & - & \multirow{3}{*}{ Mixotrophic, batch } & Proteins & 2.59 & [31] \\
\hline & & Glucose $(5 \mathrm{~g} / \mathrm{L})$, galactose $(5 \mathrm{~g} / \mathrm{L})$ & & Proteins + Lipids & 3.58 & [105] \\
\hline & & Lactose $(10 \mathrm{~g} / \mathrm{L})$ & & Proteins + lipids & 2.10 & [106] \\
\hline \multirow{3}{*}{ Chlorella protothecoides } & & Glucose $(10 \mathrm{~g} / \mathrm{L})$, galactose $(10 \mathrm{~g} / \mathrm{L})$ & Heterotrophic, Fed-batch & \multirow[b]{2}{*}{ Lipids } & 2.8 & [107] \\
\hline & & $\begin{array}{l}\text { Lactose }(9.52 \mathrm{~g} / \mathrm{L}) \text {, glucose }(4.53 \mathrm{~g} / \mathrm{L}) \\
\text { galactose }(0.24 \mathrm{~g} / \mathrm{L})\end{array}$ & \multirow{7}{*}{ Mixotrophic, batch } & & 4.54 & [108] \\
\hline & & Lactose $(4.69 \mathrm{~g} / \mathrm{L})$ & & Pigments & 3.60 & [109] \\
\hline Chlorella sp. & & \multirow{2}{*}{ Lactose $(3.37 \mathrm{~g} / \mathrm{L})$} & & \multirow{5}{*}{ Lipids } & 1.62 & [110] \\
\hline Chlamydomonas sp. & & & & & 1.15 & \\
\hline Scenedesmus obliqqus & & \multirow{2}{*}{ Lactose $(40 \mathrm{~g} / \mathrm{L})$} & & & 4.9 & [111] \\
\hline $\begin{array}{c}\text { Scenedesmus obliqqus + Chlorella } \\
\text { protothecoides }\end{array}$ & & & & & 10.6 & [112] \\
\hline Chlorella sp. & Dairy manure & NA & & & - & [113] \\
\hline \multicolumn{7}{|c|}{ Wine industry and other waste } \\
\hline Chlorella vulgaris & \multirow{2}{*}{ White wine lees } & NA & Mixotrophic, batch & Proteins & 1.75 & [31] \\
\hline Chlorella sorokinana & & & Mixotrophic, Fed-batch & \multirow{2}{*}{ Lipids } & 4 & [114] \\
\hline Chlorella sp. & Livestock compost & NA & Mixotrophic, batch & & 2.88 & [115] \\
\hline
\end{tabular}


Cultivation of $C$. pyrenoidosa in FWH resulted in 1.5-fold higher cell biomass along with accumulation of carbohydrates $(30 \%)$, lipids $(20 \%)$ and proteins $(14 \%)$ as compared to standard media supplemented with glucose [88]. The same authors also reported continuous cultivation of the microalga in FWH at dilution rates of $0.91 / \mathrm{d}, 0.72 / \mathrm{d}$, and 0.36/d [89]. The maximum dry cell weight (DCW) of $25 \mathrm{~g} / \mathrm{L}$ was recorded at a $0.72 / \mathrm{d}$ dilution rate with $28 \%$ lipid, $35 \%$ carbohydrate and $28 \%$ protein content. Another study tested various strengths of FWH $(0-100 \%)$ with the addition of inorganic fertilizers for cultivating C. vulgaris for lipid production [86]. The maximum lipid content $(219 \mathrm{mg} / \mathrm{g})$ was reported in $25 \% \mathrm{FWH}$, while the maximum protein content $(128 \mathrm{mg} / \mathrm{g})$ was recorded in $35 \% \mathrm{FWH}$, and maximum carbohydrate in $75 \% \mathrm{FWH}$. These results indicate that the desired end product can be maximized by adjusting the strength of FWH. The utilization of restaurant and bakery waste hydrolysate was tested by cultivating Galdieria sulphuraria in heterotrophic mode (Table 2). Both hydrolysates were diluted to obtain $5 \mathrm{~g} / \mathrm{L}$ of glucose and were supplemented with $0.5 \mathrm{~g} / \mathrm{L}$ of ammonia [85]. Similar specific growth rates were recorded in the control and diluted restaurant waste hydrolysate (1.22/d) followed by bakery waste hydrolysate (1.12/d). Comparison of various dilutions of FWH (10, 20 and 30\%) in pure sugars during Chlorella sp. cultivation showed a maximum DCW $(6.9 \mathrm{~g} / \mathrm{L})$ in FWH 20 being 1.13-, 1.97- and 1.35-fold higher than in glucose, glycerol, and acetate, respectively [84]. The authors also conducted semi-continuous cultivation of Chlorella sp. in a 2-L benchtop bioreactor for 18 days, which resulted in lipid productivity of $0.41 \mathrm{~g} / \mathrm{L} / \mathrm{d}$. A recent study showed an increase in DCW $(9.02 \mathrm{~g} / \mathrm{L})$ and lipid content $(65.62 \%)$ in Auxenochlorella protothecoides cultivated in FWH as compared to pure glucose (7.66 g/L and 64.52\%) [90].

The same research group in another study reported the utilization of FWH for combined DHA and squalene production from Aurantiochytrium sp. T66 [93]. An enhanced DHA production of $2.15 \mathrm{~g} / \mathrm{L}$ and squalene production of $1.05 \mathrm{~g} / \mathrm{L}$ was recorded with FWH-cultivated microalgal cells [93]. Similarly, a higher EPA content (130 $\mathrm{\mu g} / \mathrm{mg}$ of biomass) was reported from Phaeodactylum tricornutum, when grown in 3\% FWH [92]. Furthermore, anaerobically digested (AD) food waste has also been utilized for biogas and bioelectricity generation using microalgae-based microbial fuel cells (MFC) (Table 2). Microalgae are placed on the cathode of the MFC to enhance oxygen production that results in enhanced bioremediation of the AD effluent along with biogas, bioelectricity, and biomass production [87]. The utilization of C. vulgaris ( $150 \mathrm{mg} / \mathrm{L}$ ) in MFC operating with AD food waste resulted in $44 \%$ chemical oxygen demand (COD) removal, $250 \mathrm{mV}$ of bioelectricity generation, and $25.8 \%$ lipid content in microalgal biomass in 6 days. On the other hand, without the microalgal strain on the cathode, only $15 \%$ COD removal was achieved, and $135.6 \mathrm{mV}$ of bioelectricity was generated. In a recent study, 150 $\mathrm{mg} / \mathrm{L}$ of a Golenkinia sp. on the cathode of an MFC using AD food waste resulted in $4.7 \mathrm{~L}$ of biogas generated, $490 \mathrm{mV}$ of bioelectricity produced, and a $32.3 \%$ lipid content in the microalgal biomass, which was significantly higher than the control (3.7 L of biogas and $350 \mathrm{mV}$ of bioelectricity) [94].

\subsubsection{Fruit Waste}

Approximately $30-40 \%$ of produced fruit is wasted ending up in municipal solid waste [98]. The fruit residue mainly comprises of fruit peels, seeds, rotten fruit waste, and pomace, which have high carbohydrate content [116]. As a result, fruit waste can serve as a carbon source for microalgae production. C. vulgaris was cultivated in fruit waste hydrolysate generated using three different pretreatment methods (dilute acid, enzymatic, and aqueous) [98]. The maximum sugar release $(26.47 \mathrm{~g} / \mathrm{L})$ was obtained using enzymatic treatment, which also resulted in the highest microalgal DCW $(45.1 \mathrm{mg} / \mathrm{L})$ and lipid content $(10.34 \mathrm{mg} / \mathrm{L})$. When orange peel extract was utilized to cultivate C. vulgaris, it enhanced algal biomass $(2.20 \mathrm{~g} / \mathrm{L})$ and fatty acid methyl content $(0.27 \mathrm{~g} / \mathrm{L})$ by 5 - and 9 -fold, respectively, compared to BG-11 medium [100]. Various fruit waste hydrolysates have also been tested for maximizing the DHA production by heterotrophic microalgae (Table 2). Banana and pineapple fruit wastes were used to cultivate Aurantiochytrium sp. in fed-batch mode [117]. The authors reported maximum lipid and DHA content of $45 \%$ and $40 \mathrm{~g} / \mathrm{L}$, respectively, and attributed the enhancement to the higher levels of vitamins B and C and trace elements (zinc, copper, and manganese), which 
aid in cell growth and lipid biosynthesis. Cultivation of the microalga in a 5-L fermenter resulted in $41.5 \mathrm{~g} / \mathrm{L}$ of DCW with $46.21 \%$ DHA content. The utilization of date syrup to cultivate C. cohnii resulted in $6.65 \mathrm{~g} / \mathrm{L}$ of DCW with $0.42 \mathrm{~g} / \mathrm{L}$ DHA in batch mode, while $42 \mathrm{~g} / \mathrm{L} \mathrm{DCW}$ and $5.65 \mathrm{~g} / \mathrm{L}$ DHA were obtained in fed-batch mode [104].

\subsubsection{Dairy Waste}

The rapid growth of the global dairy industry has led to a significant increase in dairy waste to 4-11 million tons annually, necessitating the development of sustainable treatment technologies [117]. Dairy residues consist of high organic and nutrient (nitrogen and phosphorous) content that can be potentially utilized to cultivate microalgae [118]. Cheese whey permeate (CWP) is a major dairy residue that contains high chemical oxygen demand (60-80 g/L) and biological oxygen demand (30-50 g/L), requiring extensive treatment before release to the environment [106]. CWP comprises mainly lactose as primary sugar along with salts and non-protein nitrogen [107]. Non-hydrolysed and hydrolysed CWP powders were utilized to cultivate $C$. vulgaris under mixotrophic conditions and compared to phototrophic growth, as well as to pure glucose and galactose media [105]. The highest DCW $(3.58 \mathrm{~g} / \mathrm{L})$, protein $(63.5 \%)$, and lipid $(46 \%)$ contents were observed with hydrolysed CWP powder, while autotrophically grown microalga showed the lowest DCW (1.22 g/L) [105]. Moreover, cells cultivated in hydrolysed CWP powder showed better productivity than in pure glucose and galactose media, indicating that additional trace elements, such as calcium and potassium, present in CWP may provide growth-stimulating properties [105]. Similarly, continuous cultivation of C. vulgaris in CWP over 5 weeks resulted in higher DCW $(2.59 \mathrm{~g} / \mathrm{L})$ and protein content $(45 \%)$, as compared to phototrophic cultivation (1.21 g/L and 42\%) [31]. Another study reported that CWP augmented the DCW (1.60 g/L) and carbohydrate content (44.85\%) of microalga compared to autotrophic growth [106]. Hydrolysed CWP was also utilized to cultivate C. protothecoides using both batch and fed-batch modes [107]. The batch cultivation resulted in higher lipid content $(42 \%)$ with a DCW of $9.1 \mathrm{~g} / \mathrm{L}$, while the fed-batch mode resulted in lower (20.5\%) lipid content, but with a higher DCW of $17.2 \mathrm{~g} / \mathrm{L}$ [107]. The authors also reported that simultaneous saccharification and fermentation (SSF) with immobilized encapsulated $\beta$-galactosidase resulted in the highest lipid content $(49.9 \%)$ and $7.3 \mathrm{~g} / \mathrm{L}$ of DCW. Moreover, sequential cultivation of S. obliquus and C. protothecoides in 40\% CWP resulted in the accumulation of higher microalgal DCW $(10.6 \mathrm{~g} / \mathrm{L})$ as compared to a monoculture of S. obliquus $(7.3 \mathrm{~g} / \mathrm{L})$ [112]. It has been reported that $S$. obliquus can hydrolyse lactose to glucose and galactose, which can then be utilized by $C$. protothecoides which is unable to metabolize lactose on its own, resulting in a higher conversion $(62 \%)$ of lactose to biomass through this synergism [112]. A recent study reported 98.2\% COD removal from a $25 \%$ CWP solution by C. protothecoides after the first treatment and $100 \%$ after the second treatment, along with the generation of $4.33 \mathrm{~g} / \mathrm{L}$ of microalgal biomass and $1.02 \mathrm{~g} / \mathrm{L}$ microalgal lipid production [108].

\subsubsection{Wine Industry and Other Waste}

The wine industry generates various residues, including de-stemmed grapes, sediments, bagasse, and lees [119]. Among these wastes, white wine lees have been utilized to cultivate microalgae for lipid and protein production (Table 2). C. sorokinana was cultivated in white wine lees (100 mM) supplemented with $20 \mathrm{mM}$ of ammonium, resulting in $0.94 \mathrm{~g} / \mathrm{L}$ of DCW and $40 \%$ lipid content [114]. When the same system was operated in the fed-batch mode for $216 \mathrm{~h}$ in a 2-L stirred tank reactor, lipid productivity was $193.4 \mathrm{mg} / \mathrm{L} / \mathrm{d}$. Furthermore, utilization of white wine lees to cultivate C. vulgaris resulted in higher protein content (48\%) compared to standard media (42\%) [31]. Finally, livestock waste has also been successfully utilized to cultivate Chlorella sp. producing $2.88 \mathrm{~g} / \mathrm{L}$ of microalgal biomass with a 33.90\% lipid content [115]. 


\section{Conclusions}

Agricultural residues, food industry waste, and wine industry waste hydrolysates are sources of renewable carbon that hold strong potential for future large-scale production of microalgal biomass and bioproducts, while helping render the economy more sustainable. In this review, we analyzed the utilization of a wide range of agricultural and food residue hydrolysates for supporting and enhancing the cultivation of numerous microalgae strains in batch, fed-batch, and continuous mode. Numerous value-added microalgal bioproducts from hydrolysates have been reported to date, including lipids for DHA, EPA, and biodiesel, proteins for animal feed, carbohydrates for biofuels, and pigments. In general, the studies have shown that microalgae biomass and lipid productivity are significantly boosted, when microalgae are cultivated heterotrophically or mixotrophically in such hydrolysates compared to pure sugars or autotrophic growth. The yield enhancement, which is attributed to the presence of additional nutrients in the hydrolysates contributing to better metabolic performance, makes hydrolysates a promising cost-effective and sustainable source of carbon and nutrients for large-scale heterotrophic/mixotrophic microalgae production.

\section{Future Perspectives}

Although numerous agricultural and food residue hydrolysates have been employed successfully at the lab scale, more research and scale-up studies are still necessary before the incorporation of hydrolysates in commercial microalgae operations. Residue pretreatment, in particular, is a key process step that affects both cost and microalgal performance. Further research should be geared towards developing robust microalgal strains capable of metabolizing a wide spectrum of hydrolysate-derived sugars, tolerating hydrolysate inhibitors, and growing mixotrophically and heterotrophically. This can be facilitated by employing mutagenesis coupled with high-throughput screening, directed metabolic engineering, and adaptive laboratory evolution to select for highly productive strains. Success in obtaining such competent strains will expand the types and inclusion rate of hydrolysates that could be utilized for cultivating microalgae. Moreover, a detailed life cycle assessment and techno-economic analysis of the integrated hydrolysate-microalgae process will be crucial to optimize materials and energy circularity, document carbon emission benefits, and prove economic feasibility for the use of agricultural and food residue hydrolysates by the microalgae industry.

Author Contributions: Conceptualization: N.A., E.M.A. and G.P.P.; Writing: E.M.A. (agricultural residues) and N.A. (food residues); Review and editing: G.P.P. All authors have read and agreed to the published version of the manuscript.

Funding: The authors wish to thank the Florida Department of Agriculture and Consumer Services (USA) for its financial support through Grant Agreement 26100.

Conflicts of Interest: The authors declare no conflict of interest.

\section{References}

1. Harada, R.; Nomura, T.; Yamada, K.; Mochida, K.; Suzuki, K. Genetic Engineering Strategies for Euglena gracilis and Its Industrial Contribution to Sustainable Development Goals: A Review. Front. Bioeng. Biotechnol. 2020, 8, 790. [CrossRef]

2. D'Imporzano, G.; Veronesi, D.; Salati, S.; Adani, F. Carbon and nutrient recovery in the cultivation of Chlorella vulgaris: A life cycle assessment approach to comparing environmental performance. J. Clean. Prod. 2018, 194, 685-694. [CrossRef]

3. Arora, N.; Patel, A.; Pruthi, P.A.; Pruthi, V. Synergistic dynamics of nitrogen and phosphorous influences lipid productivity in Chlorella minutissima for biodiesel production. Bioresour. Technol. 2016, 213, $79-87$. [CrossRef]

4. Vigani, M.; Parisi, C.; Rodríguez-Cerezo, E.; Barbosa, M.J.; Sijtsma, L.; Ploeg, M.; Enzing, C. Food and feed products from micro-algae: Market opportunities and challenges for the EU. Trends Food Sci. Technol. 2015, 42, 81-92. [CrossRef] 
5. Koyande, A.K.; Chew, K.W.; Rambabu, K.; Tao, Y.; Chu, D.-T.; Show, P.-L. Microalgae: A potential alternative to health supplementation for humans. Food Sci. Hum. Wellness 2019, 8, 16-24. [CrossRef]

6. Rizwan, M.; Mujtaba, G.; Memon, S.A.; Lee, K.; Rashid, N. Exploring the potential of microalgae for new biotechnology applications and beyond: A review. Renew. Sustain. Energy Rev. 2018, 92, 394-404. [CrossRef]

7. Vanthoor-Koopmans, M.; Wijffels, R.H.; Barbosa, M.J.; Eppink, M.H.M. Biorefinery of microalgae for food and fuel. Bioresour. Technol. 2013, 135, 142-149. [CrossRef]

8. Batista, A.P.; Niccolai, A.; Fradinho, P.; Fragoso, S.; Bursic, I.; Rodolfi, L.; Biondi, N.; Tredici, M.R.; Sousa, I.; Raymundo, A. Microalgae biomass as an alternative ingredient in cookies: Sensory, physical and chemical properties, antioxidant activity and in vitro digestibility. Algal Res. 2017, 26, 161-171. [CrossRef]

9. Gong, M.; Bassi, A. Carotenoids from microalgae: A review of recent developments. Biotechnol. Adv. 2016, 34, 1396-1412. [CrossRef]

10. Sathasivam, R.; Radhakrishnan, R.; Hashem, A.; Abd_Allah, E.F. Microalgae metabolites: A rich source for food and medicine. Saudi J. Biol. Sci. 2019, 26, 709-722. [CrossRef]

11. Manirafasha, E.; Ndikubwimana, T.; Zeng, X.; Lu, Y.; Jing, K. Phycobiliprotein: Potential microalgae derived pharmaceutical and biological reagent. Biochem. Eng. J. 2016, 109, 282-296. [CrossRef]

12. Grossmann, L.; Hinrichs, J.; Weiss, J. Cultivation and downstream processing of microalgae and cyanobacteria to generate protein-based technofunctional food ingredients. Crit. Rev. Food Sci. Nutr. 2019, 1-29. [CrossRef]

13. Koutra, E.; Tsafrakidou, P.; Sakarika, M.; Kornaros, M. Microalgal Biorefinery. In Microalgae Cultivation for Biofuels Production; Elsevier: Amsterdam, The Netherlands, 2020; pp. 163-185. ISBN 978-0-12-817536-1.

14. Hossain, N.; Zaini, J.; Indra Mahlia, T.M. Life cycle assessment, energy balance and sensitivity analysis of bioethanol production from microalgae in a tropical country. Renew. Sustain. Energy Rev. 2019, 115, 109371. [CrossRef]

15. Zhang, Y.; Kendall, A. Effects of system design and Co-product treatment strategies on the life cycle performance of biofuels from microalgae. J. Clean. Prod. 2019, 230, 536-546. [CrossRef]

16. Bussa, M.; Eisen, A.; Zollfrank, C.; Röder, H. Life cycle assessment of microalgae products: State of the art and their potential for the production of polylactid acid. J. Clean. Prod. 2019, 213, 1299-1312. [CrossRef]

17. Zanette, C.M.; Mariano, A.B.; Yukawa, Y.S.; Mendes, I.; Rigon Spier, M. Microalgae mixotrophic cultivation for $\beta$-galactosidase production. J. Appl. Phycol. 2019, 31, 1597-1606. [CrossRef]

18. Arora, N.; Laurens, L.M.L.; Sweeney, N.; Pruthi, V.; Poluri, K.M.; Pienkos, P.T. Elucidating the unique physiological responses of halotolerant Scenedesmus sp. cultivated in sea water for biofuel production. Algal Res. 2019, 37, 260-268. [CrossRef]

19. Xin, X.; Huang, G.; Liu, X.; An, C.; Yao, Y.; Weger, H.; Zhang, P.; Chen, X. Molecular toxicity of triclosan and carbamazepine to green algae Chlorococcum sp.: A single cell view using synchrotron-based Fourier transform infrared spectromicroscopy. Environ. Pollut. 2017, 226, 12-20. [CrossRef]

20. Alonso, D.L.; Maroto, F.G. Plants as 'chemical factories' for the production of polyunsaturated fatty acids. Biotechnol. Adv. 2000, 18, 481-497. [CrossRef]

21. Manisali, A.Y.; Sunol, A.K.; Philippidis, G.P. Effect of macronutrients on phospholipid production by the microalga Nannochloropsis oculata in a photobioreactor. Algal Res. 2019, 41, 101514. [CrossRef]

22. Sniffen, K.D.; Price, J.R.; Sales, C.M.; Olson, M.S. Influence of Scale on Biomass Growth and Nutrient Removal in an Algal-Bacterial Leachate Treatment System. Environ. Sci. Technol. 2017, 51, 13344-13352. [CrossRef]

23. Rahman, A.; Agrawal, S.; Nawaz, T.; Pan, S.; Selvaratnam, T. A Review of Algae-Based Produced Water Treatment for Biomass and Biofuel Production. Water 2020, 12, 2351. [CrossRef]

24. Oswald, W.J.; Gotaas, H.B.; Ludwig, H.F.; Lynch, V. Algae symbiosis in oxidation ponds: III. Photosynthetic oxygenenation. JSTOR 1953, 25, 692-705.

25. Gupta, P.L.; Choi, H.-J.; Pawar, R.R.; Jung, S.P.; Lee, S.-M. Enhanced biomass production through optimization of carbon source and utilization of wastewater as a nutrient source. J. Environ. Manag. 2016, 184, 585-595. [CrossRef]

26. Dogaris, I.; Loya, B.; Cox, J.; Philippidis, G. Study of landfill leachate as a sustainable source of water and nutrients for algal biofuels and bioproducts using the microalga Picochlorum oculatum in a novel scalable bioreactor. Bioresour. Technol. 2019, 282, 18-27. [CrossRef]

27. Arora, N.; Jaiswal, K.K.; Kumar, V.; Vlaskin, M.S.; Nanda, M.; Pruthi, V.; Chauhan, P. Small-scale phyco-mitigation of raw urban wastewater integrated with biodiesel production and its utilization for aquaculture. Bioresour. Technol. 2020, 297, 122489. [CrossRef] 
28. Chew, K.W.; Yap, J.Y.; Show, P.L.; Suan, N.H.; Juan, J.C.; Ling, T.C.; Lee, D.-J.; Chang, J.-S. Microalgae biorefinery: High value products perspectives. Bioresour. Technol. 2017, 229, 53-62. [CrossRef]

29. Batista, A.P.; Niccolai, A.; Bursic, I.; Sousa, I.; Raymundo, A.; Rodolfi, L.; Biondi, N.; Tredici, M.R. Microalgae as Functional Ingredients in Savory Food Products: Application to Wheat Crackers. Foods 2019, 8, 611. [CrossRef]

30. Sim, S.J.; Joun, J.; Hong, M.E.; Patel, A.K. Split mixotrophy: A novel cultivation strategy to enhance the mixotrophic biomass and lipid yields of Chlorella protothecoides. Bioresour. Technol. 2019, 291, 121820. [CrossRef]

31. Salati, S.; D’Imporzano, G.; Menin, B.; Veronesi, D.; Scaglia, B.; Abbruscato, P.; Mariani, P.; Adani, F. Mixotrophic cultivation of Chlorella for local protein production using agro-food by-products. Bioresour. Technol. 2017, 230, 82-89. [CrossRef]

32. Bentsen, N.S.; Felby, C.; Thorsen, B.J. Agricultural residue production and potentials for energy and materials services. Prog. Energy Combust. Sci. 2014, 40, 59-73. [CrossRef]

33. Iqbal, H.M.N.; Kyazze, G.; Keshavarz, T. Advances in the valorization of lignocellulosic materials by biotechnology: An overview. BioResources 2013, 8, 3157-3176.

34. Isikgor, F.H.; Becer, C.R. Lignocellulosic biomass: A sustainable platform for the production of bio-based chemicals and polymers. Polym. Chem. 2015, 6, 4497-4559. [CrossRef]

35. Menon, V.; Rao, M. Trends in bioconversion of lignocellulose: Biofuels, platform chemicals \& biorefinery concept. Prog. Energy Combust. Sci. 2012, 38, 522-550.

36. Behera, S.; Arora, R.; Nandhagopal, N.; Kumar, S. Importance of chemical pretreatment for bioconversion of lignocellulosic biomass. Renew. Sustain. Energy Rev. 2014, 36, 91-106. [CrossRef]

37. Chaturvedi, V.; Verma, P. An overview of key pretreatment processes employed for bioconversion of lignocellulosic biomass into biofuels and value added products. 3 Biotech 2013, 3, 415-431. [CrossRef]

38. Jönsson, L.J.; Martín, C. Pretreatment of lignocellulose: Formation of inhibitory by-products and strategies for minimizing their effects. Bioresour. Technol. 2016, 199, 103-112. [CrossRef]

39. Mtui, G.Y. Recent advances in pretreatment of lignocellulosic wastes and production of value added products. Afr. J. Biotechnol. 2009, 8, 1398-1415.

40. Takkellapati, S.; Li, T.; Gonzalez, M.A. An overview of biorefinery-derived platform chemicals from a cellulose and hemicellulose biorefinery. Clean Technol. Environ. Policy 2018, 20, 1615-1630. [CrossRef]

41. Gustavsson, J.; Cederberg, C.; Sonesson, U.; Van Otterdijk, R.; Meybeck, A. Global Food Losses and Food Waste-Extent, Causes and Prevention. Food and Agriculture Organization (FAO). 2011. Available online: http://www.fao.org/3/a-i2697e.pdf (accessed on 4 October 2020).

42. Lipinski, B.; Hanson, C.; Lomax, J.; Kitinoja, L.; Waite, R.; Searchinger, T. Reducing food loss and waste. World Resour. Inst. Work. Paper 2013, 1, 1-40.

43. Buzby, J.C.; Farah-Wells, H.; Hyman, J. The estimated amount, value, and calories of postharvest food losses at the retail and consumer levels in the United States. USDA-ERS Econ. Inf. Bull. 2014, 121, 1-39. [CrossRef]

44. Bilal, M.; Iqbal, H.M. Sustainable bioconversion of food waste into high-value products by immobilized enzymes to meet bio-economy challenges and opportunities-A review. Food Res. Int. 2019, 123, 226-240. [PubMed]

45. Liang, Y.; Sarkany, N.; Cui, Y.; Yesuf, J.; Trushenski, J.; Blackburn, J.W. Use of sweet sorghum juice for lipid production by Schizochytrium limacinum SR21. Bioresour. Technol. 2010, 101, 3623-3627. [CrossRef] [PubMed]

46. Gao, C.; Zhai, Y.; Ding, Y.; Wu, Q. Application of sweet sorghum for biodiesel production by heterotrophic microalga Chlorella protothecoides. Appl. Energy 2010, 87, 756-761.

47. Cheng, Y.; Zhou, W.; Gao, C.; Lan, K.; Gao, Y.; Wu, Q. Biodiesel production from Jerusalem artichoke (Helianthus Tuberosus L.) tuber by heterotrophic microalgae Chlorella protothecoides. J. Chem. Technol. Biotechnol. Int. Res. Process Environ. Clean Technol. 2009, 84, 777-781.

48. Kim, M.; Cho, J.M.; Kim, H.S.; Lee, H.; Oh, H.-M.; Chang, Y.K. Heterotrophic cultivation of Ettlia sp. based on sequential hydrolysis of Helianthus tuberosus and algal residue. Energy Convers. Manag. 2020, 211, 112769. [CrossRef]

49. Xu, H.; Miao, X.; Wu, Q. High quality biodiesel production from a microalga Chlorella protothecoides by heterotrophic growth in fermenters. J. Biotechnol. 2006, 126, 499-507. 
50. Wei, A.; Zhang, X.; Wei, D.; Chen, G.; Wu, Q.; Yang, S.-T. Effects of cassava starch hydrolysate on cell growth and lipid accumulation of the heterotrophic microalgae Chlorella protothecoides. J. Ind. Microbiol. Biotechnol. 2009, 36, 1383.

51. Lu, Y.; Zhai, Y.; Liu, M.; Wu, Q. Biodiesel production from algal oil using cassava (Manihot esculenta Crantz) as feedstock. J. Appl. Phycol. 2010, 22, 573-578.

52. Lu, Y.; Ding, Y.; Wu, Q. Simultaneous saccharification of cassava starch and fermentation of algae for biodiesel production. J. Appl. Phycol. 2011, 23, 115-121.

53. Salim, M.A. Biomass and lipid content of heterotrophic Spirogyra sp by using cassava starch hydrolysate. Int. J. Eng. Res. Dev. 2012, 6, 21-26.

54. Salim, M.A. Heterotrophic growth of Ankistrodesmus sp. for lipid production using cassava starch hydrolysate as a carbon source. Int. J. Biotechnol. 2013, 2, 42-51.

55. Barrocal, V.M.; García-Cubero, M.T.; González-Benito, G.; Coca, M. Production of biomass by Spirulina maxima using sugar beet vinasse in growth media. New Biotechnol. 2010, 27, 851-856. [CrossRef] [PubMed]

56. Coca, M.; Barrocal, V.M.; Lucas, S.; González-Benito, G.; García-Cubero, M.T. Protein production in Spirulina platensis biomass using beet vinasse-supplemented culture media. Food Bioprod. Process. 2015, 94, 306-312. [CrossRef]

57. Marques, S.S.I.; Nascimento, I.A.; De Almeida, P.F.; Chinalia, F.A. Growth of Chlorella vulgaris on sugarcane vinasse: The effect of anaerobic digestion pretreatment. Appl. Biochem. Biotechnol. 2013, 171, 1933-1943. [CrossRef]

58. Ramirez, N.N.V.; Farenzena, M.; Trierweiler, J.O. Growth of microalgae Scenedesmus sp in ethanol vinasse. Braz. Arch. Biol. Technol. 2014, 57, 630-635. [CrossRef]

59. Dos Santos, R.R.; Araújo, O.; De Medeiros, J.L.; Chaloub, R.M. Cultivation of Spirulina maxima in medium supplemented with sugarcane vinasse. Bioresour. Technol. 2016, 204, 38-48. [CrossRef]

60. Santana, H.; Cereijo, C.R.; Teles, V.C.; Nascimento, R.C.; Fernandes, M.S.; Brunale, P.; Campanha, R.C.; Soares, I.P.; Silva, F.C.; Sabaini, P.S. Microalgae cultivation in sugarcane vinasse: Selection, growth and biochemical characterization. Bioresour. Technol. 2017, 228, 133-140. [CrossRef]

61. El-sheekh, M.M.; Bedaiwy, M.Y.; Osman, M.E.; Ismail, M.M. Mixotrophic and heterotrophic growth of some microalgae using extract of fungal-treated wheat bran. Int. J. Recycl. Org. Waste Agric. 2012, 1, 12. [CrossRef]

62. Gélinas, M.; Pham, T.T.H.; Boëns, B.; Adjallé, K.; Barnabé, S. Residual corn crop hydrolysate and silage juice as alternative carbon sources in microalgae production. Algal Res. 2015, 12, 33-42. [CrossRef]

63. Li, P.; Miao, X.; Li, R.; Zhong, J. In situ biodiesel production from fast-growing and high oil content Chlorella pyrenoidosa in rice straw hydrolysate. BioMed Res. Int. 2011, 2011, 1-9. [CrossRef]

64. Bindra, S.; Kulshrestha, S. Converting waste to energy: Production and characterization of biodiesel from Chlorella pyrenoidosa grown in a medium designed from waste. Renew. Energy 2019, 142, 415-425. [CrossRef]

65. Joe, M.-H.; Kim, J.-Y.; Lim, S.; Kim, D.-H.; Bai, S.; Park, H.; Lee, S.G.; Han, S.J.; Choi, J. Microalgal lipid production using the hydrolysates of rice straw pretreated with gamma irradiation and alkali solution. Biotechnol. Biofuels 2015, 8, 125. [CrossRef] [PubMed]

66. Perez, M.; Nolasco, N.A.; Vasavada, A.; Johnson, M.; Kuehnle, A. Algae-mediated valorization of industrial waste streams. Ind. Biotechnol. 2015, 11, 229-234. [CrossRef]

67. Miazek, K.; Remacle, C.; Richel, A.; Goffin, D. Beech wood Fagus sylvatica dilute-acid hydrolysate as a feedstock to support Chlorella sorokiniana biomass, fatty acid and pigment production. Bioresour. Technol. 2017, 230, 122-131. [CrossRef]

68. Lage, S.; Kudahettige, N.P.; Ferro, L.; Matsakas, L.; Funk, C.; Rova, U.; Gentili, F.G. Microalgae Cultivation for the Biotransformation of Birch Wood Hydrolysate and Dairy Effluent. Catalysts 2019, 9, 150. [CrossRef]

69. Patel, A.; Rova, U.; Christakopoulos, P.; Matsakas, L. Simultaneous production of DHA and squalene from Aurantiochytrium sp. grown on forest biomass hydrolysates. Biotechnol. Biofuels 2019, 12, 255. [CrossRef]

70. Chen, J.; Liu, X.; Wei, D.; Chen, G. High yields of fatty acid and neutral lipid production from cassava bagasse hydrolysate (CBH) by heterotrophic Chlorella protothecoides. Bioresour. Technol. 2015, 191, 281-290. [CrossRef]

71. Liu, L.; Chen, J.; Lim, P.-E.; Wei, D. Enhanced single cell oil production by mixed culture of Chlorella pyrenoidosa and Rhodotorula glutinis using cassava bagasse hydrolysate as carbon source. Bioresour. Technol. 2018, 255, 140-148. [CrossRef] 
72. Mu, J.; Li, S.; Chen, D.; Xu, H.; Han, F.; Feng, B.; Li, Y. Enhanced biomass and oil production from sugarcane bagasse hydrolysate ( $\mathrm{SBH}$ ) by heterotrophic oleaginous microalga Chlorella protothecoides. Bioresour. Technol. 2015, 185, 99-105. [CrossRef]

73. Pelizer, L.H.; De Carvalho, J.C.M.; De Oliveira Moraes, I. Protein production by Arthrospira (Spirulina) platensis in solid state cultivation using sugarcane bagasse as support. Biotechnol. Rep. 2015, 5, 70-76. [CrossRef] [PubMed]

74. Arora, N.; Patel, A.; Pruthi, P.A.; Pruthi, V. Boosting TAG accumulation with improved biodiesel production from novel oleaginous microalgae Scenedesmus sp. IITRIND2 utilizing waste sugarcane bagasse aqueous extract (SBAE). Appl. Biochem. Biotechnol. 2016, 180, 109-121. [CrossRef] [PubMed]

75. Manzoor, M.; Ahmad, Q.; Aslam, A.; Jabeen, F.; Rasul, A.; Schenk, P.M.; Qazi, J.I. Mixotrophic cultivation of Scenedesmus dimorphus in sugarcane bagasse hydrolysate. Environ. Prog. Sustain. Energy 2020, 39 , e13334.

76. Nguyen, H.C.; Su, C.-H.; Yu, Y.-K.; Huong, D.T.M. Sugarcane bagasse as a novel carbon source for heterotrophic cultivation of oleaginous microalga Schizochytrium sp. Ind. Crops Prod. 2018, 121, $99-105$. [CrossRef]

77. Gong, Y.; Liu, J.; Jiang, M.; Liang, Z.; Jin, H.; Hu, X.; Wan, X.; Hu, C. Improvement of omega-3 docosahexaenoic acid production by marine dinoflagellate Crypthecodinium cohnii using rapeseed meal hydrolysate and waste molasses as feedstock. PLoS ONE 2015, 10, e0125368.

78. Ali, M.; Rajewski, J.; Baenziger, P.; Gill, K.; Eskridge, K.; Dweikat, I. Assessment of genetic diversity and relationship among a collection of US sweet sorghum germplasm by SSR markers. Mol. Breed. 2008, 21, 497-509. [CrossRef]

79. Matsakas, L.; Sterioti, A.-A.; Rova, U.; Christakopoulos, P. Use of dried sweet sorghum for the efficient production of lipids by the yeast Lipomyces starkeyi CBS 1807. Ind. Crop. Prod. 2014, 62, 367-372. [CrossRef]

80. Lo, E.; Brabo-Catala, L.; Dogaris, I.; Ammar, E.M.; Philippidis, G.P. Biochemical conversion of sweet sorghum bagasse to succinic acid. J. Biosci. Bioeng. 2020, 129, 104-109. [CrossRef]

81. Ammar, E.M.; Martin, J.; Brabo-Catala, L.; Philippidis, G.P. Propionic acid production by Propionibacterium freudenreichii using sweet sorghum bagasse hydrolysate. Appl. Microbiol. Biotechnol. 2020, 104, 9619-9629. [CrossRef]

82. Rodrigues Reis, C.E.; Hu, B. Vinasse from Sugarcane Ethanol Production: Better Treatment or Better Utilization? Front. Energy Res. 2017, 5, 7. [CrossRef]

83. Kwan, T.H.; Pleissner, D.; Lau, K.Y.; Venus, J.; Pommeret, A.; Lin, C.S.K. Techno-economic analysis of a food waste valorization process via microalgae cultivation and co-production of plasticizer, lactic acid and animal feed from algal biomass and food waste. Bioresour. Technol. 2015, 198, 292-299. [CrossRef] [PubMed]

84. Wang, X.; Zhang, M.-M.; Sun, Z.; Liu, S.-F.; Qin, Z.-H.; Mou, J.-H.; Zhou, Z.-G.; Lin, C.S.K. Sustainable lipid and lutein production from Chlorella mixotrophic fermentation by food waste hydrolysate. J. Hazard. Mater. 2020, 400, 123258. [CrossRef] [PubMed]

85. Sloth, J.K.; Jensen, H.C.; Pleissner, D.; Eriksen, N.T. Growth and phycocyanin synthesis in the heterotrophic microalga Galdieria sulphuraria on substrates made of food waste from restaurants and bakeries. Bioresour. Technol. 2017, 238, 296-305. [CrossRef] [PubMed]

86. Chew, K.W.; Chia, S.R.; Show, P.L.; Ling, T.C.; Arya, S.S.; Chang, J.-S. Food waste compost as an organic nutrient source for the cultivation of Chlorella vulgaris. Bioresour. Technol. 2018, 267, 356-362. [CrossRef]

87. Hou, Q.; Pei, H.; Hu, W.; Jiang, L.; Yu, Z. Mutual facilitations of food waste treatment, microbial fuel cell bioelectricity generation and Chlorella vulgaris lipid production. Bioresour. Technol. 2016, 203, 50-55. [CrossRef]

88. Pleissner, D.; Lin, C.S.K. Valorisation of food waste in biotechnological processes. Sustain. Chem. Process. 2013, 1, 21. [CrossRef]

89. Pleissner, D.; Lau, K.Y.; Schneider, R.; Venus, J.; Lin, C.S.K. Fatty acid feedstock preparation and lactic acid production as integrated processes in mixed restaurant food and bakery wastes treatment. Food Res. Int. 2015, 73, 52-61. [CrossRef]

90. Patel, A.; Matsakas, L.; Hrůzová, K.; Rova, U.; Christakopoulos, P. Biosynthesis of Nutraceutical Fatty Acids by the Oleaginous Marine Microalgae Phaeodactylum tricornutum Utilizing Hydrolysates from Organosolv-Pretreated Birch and Spruce Biomass. Mar. Drugs 2019, 17, 119. [CrossRef] 
91. Haske-Cornelius, O.; Vu, T.; Schmiedhofer, C.; Vielnascher, R.; Dielacher, M.; Sachs, V.; Grasmug, M.; Kromus, S.; Guebitz, G.M. Cultivation of heterotrophic algae on enzymatically hydrolyzed municipal food waste. Algal Res. 2020, 50, 101993. [CrossRef]

92. Wang, X.; Balamurugan, S.; Liu, S.-F.; Zhang, M.-M.; Yang, W.-D.; Liu, J.-S.; Li, H.-Y.; Lin, C.S.K. Enhanced polyunsaturated fatty acid production using food wastes and biofuels byproducts by an evolved strain of Phaeodactylum tricornutum. Bioresour. Technol. 2020, 296, 122351. [CrossRef]

93. Patel, A.; Rova, U.; Christakopoulos, P.; Matsakas, L. Mining of squalene as a value-added byproduct from DHA producing marine thraustochytrid cultivated on food waste hydrolysate. Sci. Total Environ. 2020, 736, 139691. [CrossRef] [PubMed]

94. Hou, Q.; Yang, Z.; Chen, S.; Pei, H. Using an anaerobic digestion tank as the anodic chamber of an algae-assisted microbial fuel cell to improve energy production from food waste. Water Res. 2020, 170, 115305. [CrossRef] [PubMed]

95. Zhang, L.; Cheng, J.; Pei, H.; Pan, J.; Jiang, L.; Hou, Q.; Han, F. Cultivation of microalgae using anaerobically digested effluent from kitchen waste as a nutrient source for biodiesel production. Renew. Energy 2018, 115, 276-287. [CrossRef]

96. Yu, Z.; Song, M.; Pei, H.; Han, F.; Jiang, L.; Hou, Q. The growth characteristics and biodiesel production of ten algae strains cultivated in anaerobically digested effluent from kitchen waste. Algal Res. 2017, 24, 265-275. [CrossRef]

97. Kamal, S.; El-Sayed, A.; Hassan, A.; El-Shazly, H.; Ibrahim, M. Use Of Okara Waste For Algae Nutrition. Arab Univ. J. Agric. Sci. 2017, 25, 271-279. [CrossRef]

98. Limbu, B.; Sibi, G. Fruit Wastes Hydrolysates as Feedstock: Pre-Treatment Strategies for Cost-Saving and Sustainable Microalgae Cultivation. Int. J. Res. Environ. Sci. 2017, 3. [CrossRef]

99. Nazir, Y.; Halim, H.; Al-Shorgani, N.K.N.; Manikan, V.; Hamid, A.A.; Song, Y. Efficient conversion of extracts from low-cost, rejected fruits for high-valued Docosahexaenoic acid production by Aurantiochytrium sp. SW1. Algal Res. 2020, 50, 101977. [CrossRef]

100. Park, W.-K.; Moon, M.; Shin, S.-E.; Cho, J.M.; Suh, W.I.; Chang, Y.K.; Lee, B. Economical DHA (Docosahexaenoic acid) production from Aurantiochytrium sp. KRS101 using orange peel extract and low cost nitrogen sources. Algal Res. 2018, 29, 71-79. [CrossRef]

101. Park, W.-K.; Moon, M.; Kwak, M.-S.; Jeon, S.; Choi, G.-G.; Yang, J.-W.; Lee, B. Use of orange peel extract for mixotrophic cultivation of Chlorella vulgaris: Increased production of biomass and FAMEs. Bioresour. Technol. 2014, 171, 343-349. [CrossRef]

102. Heller, W.P.; Kissinger, K.R.; Matsumoto, T.K.; Keith, L.M. Utilization of papaya waste and oil production by Chlorella protothecoides. Algal Res. 2015, 12, 156-160. [CrossRef]

103. Ghosh, U.K. An approach for phycoremediation of different wastewaters and biodiesel production using microalgae. Environ. Sci. Pollut. Res. 2018, 25, 18673-18681. [CrossRef]

104. Rumiani, L.A.; Jalili, H.; Amrane, A. Enhanced docosahexaenoic acid production by Crypthecodinium cohnii under combined stress in two-stage cultivation with date syrup based medium. Algal Res. 2018, 34, 75-81. [CrossRef]

105. Abreu, A.P.; Fernandes, B.; Vicente, A.A.; Teixeira, J.; Dragone, G. Mixotrophic cultivation of Chlorella vulgaris using industrial dairy waste as organic carbon source. Bioresour. Technol. 2012, 118, 61-66. [CrossRef] [PubMed]

106. De Melo, R.G.; De Andrade, A.F.; Bezerra, R.P.; Correia, D.S.; De Souza, V.C.; Brasileiro-Vidal, A.C.; De·Araújo Viana Marques, D.; Porto, A.L.F. Chlorella vulgaris mixotrophic growth enhanced biomass productivity and reduced toxicity from agro-industrial by-products. Chemosphere 2018, 204, 344-350. [CrossRef] [PubMed]

107. Espinosa-Gonzalez, I.; Parashar, A.; Bressler, D.C. Heterotrophic growth and lipid accumulation of Chlorella protothecoides in whey permeate, a dairy by-product stream, for biofuel production. Bioresour. Technol. 2014, 155, 170-176. [CrossRef]

108. Patel, A.K.; Choi, Y.Y.; Sim, S.J. Emerging prospects of mixotrophic microalgae: Way forward to sustainable bioprocess for environmental remediation and cost-effective biofuels. Bioresour. Technol. 2020, 300, 122741. [CrossRef] 
109. Ribeiro, J.E.S.; Martini, M.; Altomonte, I.; Salari, F.; Nardoni, S.; Sorce, C.; Da Silva, F.L.H.; Andreucci, A. Production of Chlorella protothecoides biomass, chlorophyll and carotenoids using the dairy industry by-product scotta as a substrate. Biocatal. Agric. Biotechnol. 2017, 11, 207-213. [CrossRef]

110. Mondal, M.; Ghosh, A.; Sharma, A.S.; Tiwari, O.N.; Gayen, K.; Mandal, M.K.; Halder, G.N. Mixotrophic cultivation of Chlorella sp. BTA 9031 and Chlamydomonas sp. BTA 9032 isolated from coal field using various carbon sources for biodiesel production. Energy Convers. Manag. 2016, 124, 297-304. [CrossRef]

111. Girard, J.-M.; Roy, M.-L.; Hafsa, M.B.; Gagnon, J.; Faucheux, N.; Heitz, M.; Tremblay, R.; Deschênes, J.-S. Mixotrophic cultivation of green microalgae Scenedesmus obliquus on cheese whey permeate for biodiesel production. Algal Res. 2014, 5, 241-248. [CrossRef]

112. Girard, J.-M.; Tremblay, R.; Faucheux, N.; Heitz, M.; Deschênes, J.-S. Phycoremediation of cheese whey permeate using directed commensalism between Scenedesmus obliquus and Chlorella protothecoides. Algal Res. 2017, 22, 122-126. [CrossRef]

113. Wang, L.; Wang, Y.; Chen, P.; Ruan, R. Semi-continuous Cultivation of Chlorella vulgaris for Treating Undigested and Digested Dairy Manures. Appl. Biochem. Biotechnol. 2010, 162, 2324-2332. [CrossRef] [PubMed]

114. León-Vaz, A.; León, R.; Díaz-Santos, E.; Vigara, J.; Raposo, S. Using agro-industrial wastes for mixotrophic growth and lipids production by the green microalga Chlorella sorokiniana. New Biotechnol. 2019, 51, 31-38. [CrossRef] [PubMed]

115. Zhu, L.-D.; Li, Z.-H.; Guo, D.-B.; Huang, F.; Nugroho, Y.; Xia, K. Cultivation of Chlorella sp. with livestock waste compost for lipid production. Bioresour. Technol. 2017, 223, 296-300. [CrossRef] [PubMed]

116. Deng, G.-F.; Shen, C.; Xu, X.-R.; Kuang, R.-D.; Guo, Y.-J.; Zeng, L.-S.; Gao, L.-L.; Lin, X.; Xie, J.-F.; Xia, E.-Q.; et al. Potential of Fruit Wastes as Natural Resources of Bioactive Compounds. IJMS 2012, 13, 8308-8323. [CrossRef] [PubMed]

117. Ahmad, T.; Aadil, R.M.; Ahmed, H.; Ur Rahman, U.; Soares, B.C.V.; Souza, S.L.Q.; Pimentel, T.C.; Scudino, H.; Guimarães, J.T.; Esmerino, E.A.; et al. Treatment and utilization of dairy industrial waste: A review. Trends Food Sci. Technol. 2019, 88, 361-372. [CrossRef]

118. Arvanitoyannis, I.S.; Giakoundis, A. Current Strategies for Dairy Waste Management: A Review. Crit. Rev. Food Sci. Nutr. 2006, 46, 379-390. [CrossRef]

119. Devesa-Rey, R.; Vecino, X.; Varela-Alende, J.L.; Barral, M.T.; Cruz, J.M.; Moldes, A.B. Valorization of winery waste vs. the costs of not recycling. Waste Manag. 2011, 31, 2327-2335. [CrossRef]

Publisher's Note: MDPI stays neutral with regard to jurisdictional claims in published maps and institutional affiliations.

(C) 2020 by the authors. Licensee MDPI, Basel, Switzerland. This article is an open access article distributed under the terms and conditions of the Creative Commons Attribution (CC BY) license (http://creativecommons.org/licenses/by/4.0/). 